\title{
50. STRUCTURE AND EVOLUTION OF THE MEDITERRANEAN BASINS
}

\author{
Bernard Biju-Duval, Jean Letouzey, and Lucien Montadert, Institut Français du Petrole \\ Rueil-Malmaison, France
}

\begin{abstract}
In this paper we attempt to reconstruct the general history of the Alpine-Mediterranean realm on the basis of geological crosssections onland and offshore, general mapping of the basins and the main structural units of the Mediterranean area, and geophysical data. The history of the Alpine-Mediterranean realm is related to the plate movements of Europe and Africa and associated with the opening of the Atlantic. After a first stage with a broad oceanic domain (Tethys), the opening of a proto-eastern Mediterranean and the formation of active margins south of Europe modified the physiegraphy until the stage of continental collision. The western and eastern Mediterranean basins differ. The western basins are very young: Oligocene-Miocene episutural and intracontinental marginal basins, recently rejuvenated (Tyrrhenian Sea) and always part of the Alpine orogenic belt. The eastern basins are remnants of a former much larger Mesozoic basin south of the still active Alpine belt. The Cyprus, Aegean, and Calabrian arcs are described successively. Diagrammatic sections and schematic maps show this Cenozoic evolution and a speculative history is presented.
\end{abstract}

\section{INTRODUCTION}

Relatively few seismic reflection data with good penetration were available in the deep Mediterranean basins at the time of the completion of DSDP Leg 13. In particular, almost no information existed on the geological structure below the top of the Messinian evaporites defined by Horizon M (Ryan, 1969). The first deep seismic information came with the use of multichannel seismic reflection which was used in 1970 to establish the seismic stratigraphy of the deep western Mediterranean basins (Montadert et al., 1970). Since that time, data accumulated by several institutions (IFP-CEPM, OGST, CNEXO, etc.) and oil companies have produced a better understanding of the general geological framework of the different Mediterranean basins (Mulder, 1973; Finetti et al., 1973; Mauffret et al., 1973; Biju-Duval et al., 1974; Morelli, 1975).

These new data enabled new objectives to be proposed for the Glomar Challenger. In particular, the possibility of exploring the pre-evaporitic series was recognized. These objectives were defined by several site surveys conducted in both the Western and Eastern Mediterranean Sea by IFP-CNEXO with multichannel seismic reflection.

Moreover, some information from offshore oil drilling has recently been published. These data are of prime importance for understanding the geological history of the margins and deep basins, and they provide an opportunity to relate land geological data and DSDP drilling data (for example, drilling in the Gulf of Lion [Cravatte et al., 1974] Gulf of Valencia, northern Algeria [Burollet et al., in press]; Israel [Gvirtzman et al., in press]; Turkey, the Aegean Sea, etc.).

All this information can be used to place the results of Leg $42 \mathrm{~A}$ in a broad geological setting and we attempt here to emphasize the contribution of Leg 42A to the reconstruction of the structural history of the Mediterranean basins (Figure 1).

Drilling and seismic reflection, however, give data mainly on the more recent geological history only: primarily the Cenozoic in the western Mediterranean and part of the Mesozoic in the eastern Mediterranean. But the recent history of these basins is related to their earlier history and we must consider the geological events that succeeded one another in the region between Africa and Eurasia before describing the present basins.

Because of the very large number of publications concerning the Mediterranean area that have appeared in the last 100 years, we cannot give a complete bibliography of all the papers considered in this synthesis. Many of them have been cited in previous papers (Biju-Duval et al., 1974; Biju-Duval, 1974). Consequently, we cite here only more recent papers or those useful for providing a general background or specific data.

\section{OUTLINE OF THE GEOLOGICAL HISTORY OF THE ALPINE-MEDITERRANEAN AREA DURING MESOZOIC AND EARLY CENOZOIC TIME}

Several attempts have previously been made to reconstruct the Alpine-Mediterranean geological his- 


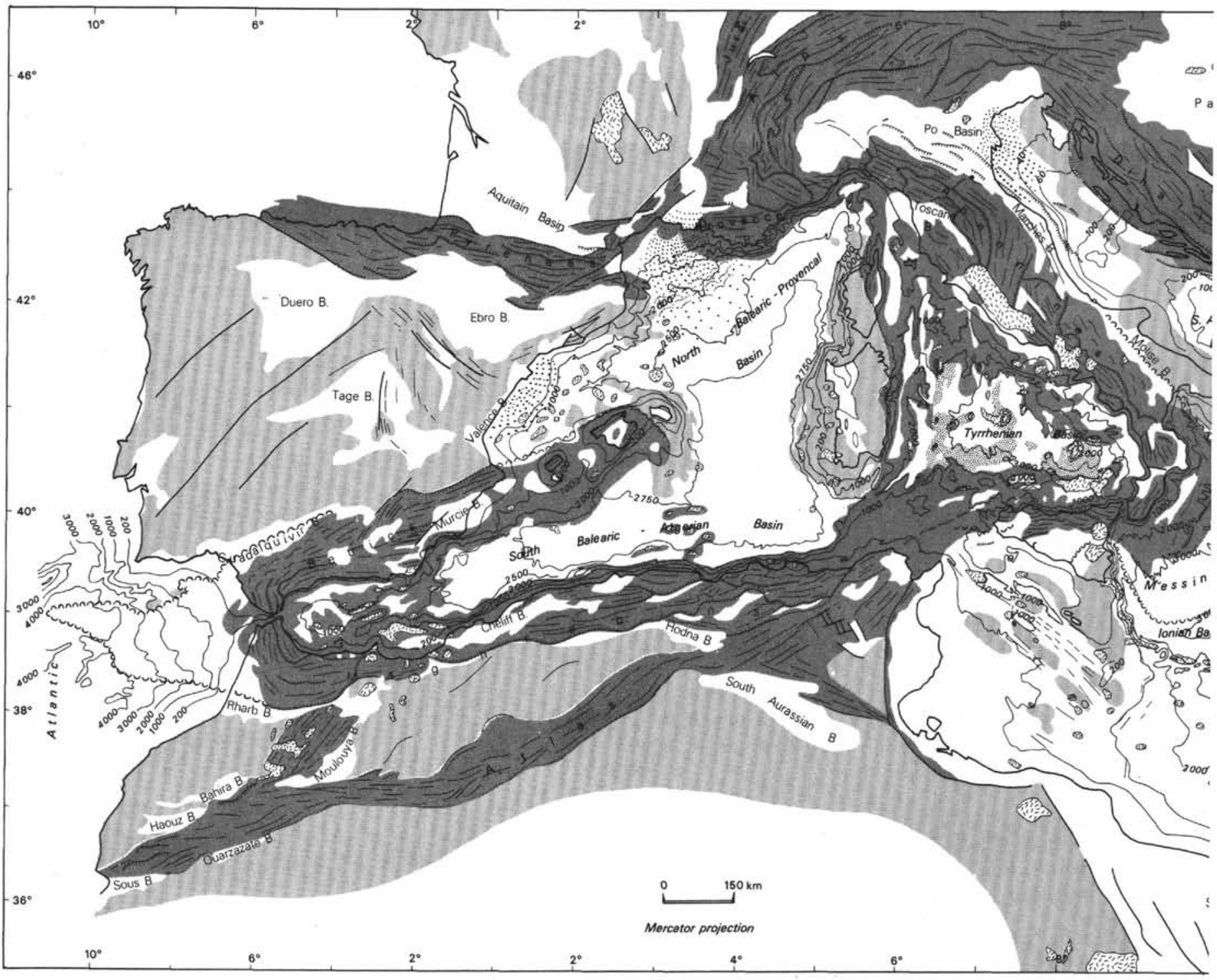

1 Sedimentary Basins

2 Stable Areas

3 Orogenic Belts

4 Main directions of folding

5 Major overthrusts, fronts of nappes

6 Major faults

a) onshore b) offshore

Figure 1. Structural map of the Mediterranean Sea.

tory following different approaches: (1) from mainly land data (for example, Klemme, 1958; Dercourt, 1970; Argyriadis, 1975; Enay, 1972; etc.); (2) from the application of plate tectonics concepts, using a reconstitution of relative movements of Europe and Africa and recognizing the geological consequences in the AlpineMediterranean area (Dewey et al., 1973); or (3) by a combination of both approaches (Bosellini et al., 1973; Trumpy, 1975; Laubscher and Bernouilli, in press).

In this paper we do not try to present a detailed. reconstruction, but to schematically present our view of the structural history of the area at different periods: pre-Mesozoic, Triassic, upper Liasic, Upper Jurassic, Upper Cretaceous, upper Eocene. We use these speculations as a starting point for the discussion of the western Mediterranean Basin, whose history began in the Oligocene, and as a general framework for the older eastern Mediterranean Basin. In this paper, we employ the broad plate tectonic framework for the Alpine-Mediterranean area which was briefly presented by Biju-Duval et al. (Split Symposium, 1976) and was discussed in detail later (Biju-Duval et al. 1977).

\section{Pre-Mesozoic (Figure 2[1])}

Many geologists and geophysicists agree that before the Mesozoic a very large Tethyan Ocean existed in the east which was connected with the Pacific Ocean. This concept of a very large ocean, however, cannot be accepted as definitive. Argyriadis (1975) cast doubt on it by arguing that no marginal- or oceanic-type Permian deposits have been found. Also, the concepts of plate kinematics, on the basis of Atlantic magnetic anomalies, do not allow for a precise fit before anomaly 32 (Santonian). Before that time a small difference in the Atlantic fit would introduce very great differences in reconstructions of the eastern part of the 


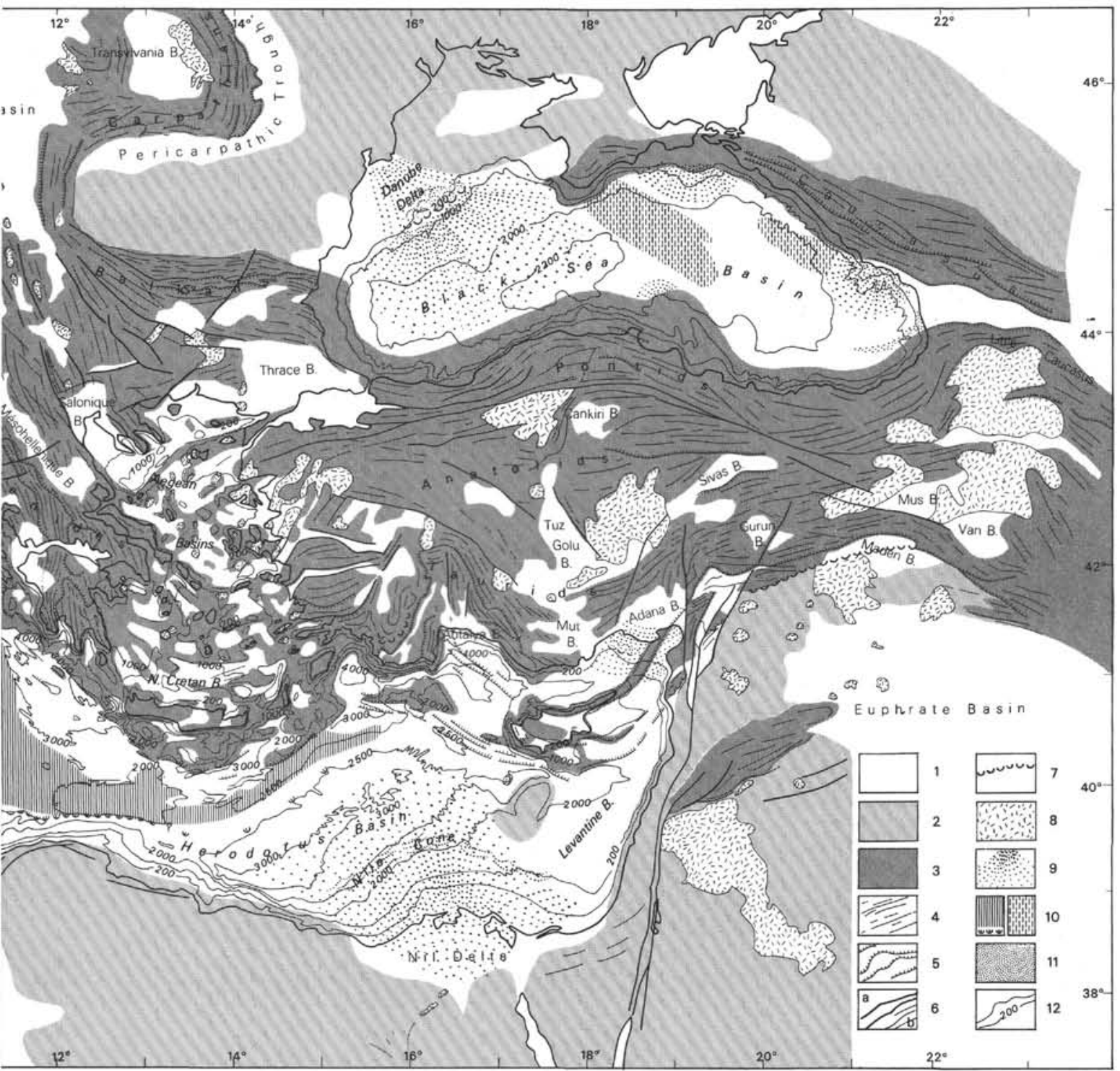

Figure 1. (Continued).

future Mediterranean area. Thus, the existence of this large Tethys is still speculative, and consequently its western extent is also questionable.

Note that all the Paleozoic massifs surrounding the western Mediterranean (Iberian Meseta, Pelvoux, Mercantour, Corsica, Sardinia, Kabylia, Menorca, etc.) were involved in the Hercynian Orogeny. The southern boundary of the Hercynian fold belt was probably located near the present Saharan flexure (Figure 2[1]). There are only a few indications of flexures, possibly related to margins of upper Carboniferous to Permian age, in the northwestern Sahara region. The Permian Djeffara flexure is an intracratonic feature. In the eastern Mediterranean, it now appears that the Paleozoic in Taurus (Turkey) is a northern extension of the Arabic-African series. It was not involved in the Hercynian Orogeny. In Yugoslavia, Greece, western Turkey (Serbo-Macedonian, Pelagonian, Cyclades,
Menderes) the metamorphic series have been so affected by later orogenies that their true nature, age, and structural position are currently being studied. For example, recently metamorphosed platform deposits of Mesozoic age have been discovered around the Menderes (5th Symposium on the Geology of Aegean Regions, 1975). Thus the pre-Triassic Tethys was located between the Hercynian fold belt to the north and the Arabic-African-Anatolian-Apulian plate in the South. To the West, the Mesozoic features are located inside the Hercynian fold belt.

\section{Triassic-Lias Period (Figure 2[2])}

In the Triassic a clear contrast in depositional environment existed between the west and the east. During the entire time the western area was receiving shallow-water marine deposits or continental deposits 


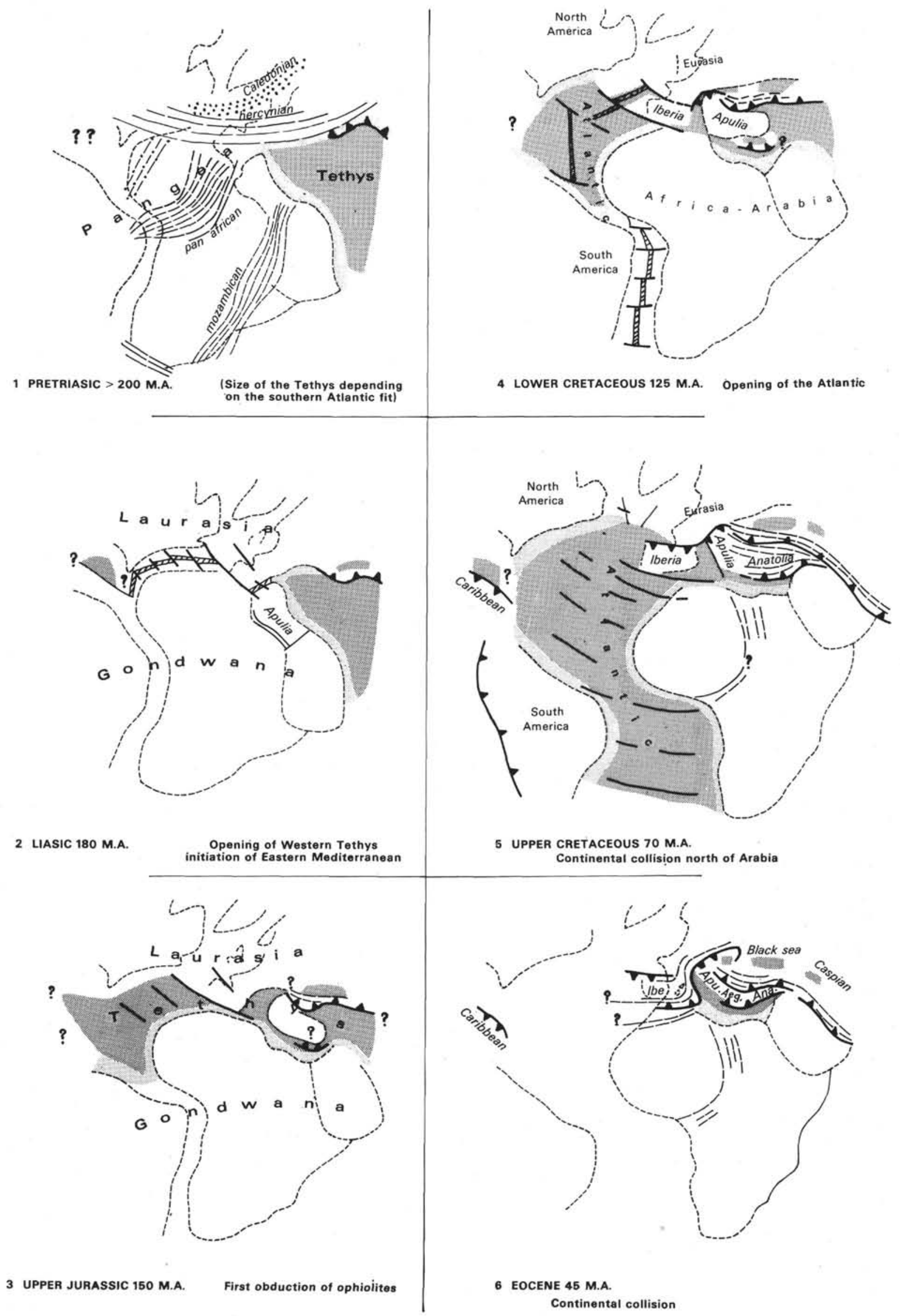

Figure 2. Tentative plate evolution in the Tethys-Alpine-Mediterranean area. 
with well-characterized brackish intercalations ("Germanic facies"'). After the Werfenian episode when continental or brackish influences predominated, a marine transgression occurred which probably came from the east (Tethys) and resulted in deposition of carbonate platform sediments. More restricted conditions with large evaporitic deposits prevailed during the upper Triassic (Keuper). In the eastern area, toward the edges of the Tethys, the presence of marine "Alpine facies" indicate the proximity of an open sea during that time. On these edges (Lombardy, Dinarides, Hellenides), platform carbonate facies merge into deep water facies, particularly in the upper Triassic deposits (Bernoulli et al., 1974; Bosellini et al., 1973). Sediments associated with ophiolites have been described, but their tectonic relationships are so complicated that it is still difficult to reconstruct their original location. Such an evolution toward deep water facies is also known west of the Apulian platform, in Sicily, and on the Israeli margin. These facts are evidence of the beginning of rifting and dispersal of the northern part of the African-Apulian plate.

Northeastward (Balkans, Crimea, Caucasus) deformation (Eo-Cimmerian foldings) which continues throughout the Lias in the Pontids (Fourquin, 1975) is explained by the existence in the area of a subduction zone. The volcanic activity of Pontids and Caucasus indicate the existence of such a subduction zone. Overthrusting affected the old ophiolites in Bulgaria, northwest Turkey, and granitization occurred.

In the western area, upper Triassic carbonate facies of the Alpujarrides and Malaguides (Internal Betic) and of the "Dorsale calcaire" (Betic and Maghrebin ranges) may indicate the beginning of a separation between Iberia and Africa, inside the Hercynian folded belt.

\section{Late Lias-Dogger Period (Figure 2[2])}

During the middle-upper Lias, there was an extension toward the West of the breaks related with Tethys with controlled facies distribution.

In the western Mediterranean area, important changes occurred. In the Alps, the "facies brianconnais" recorded a remarkable Lias distension; following carbonate deposition on a subsided platform, a large island emerged between two deep subsiding blocks (Bourbon et al., 1975). Dogger pelagic facies are widely distributed. In southern Spain and North Africa, terrigenous facies developed locally, and the oolitic or reefal carbonates of the internal zones indicate that a significant change in the geography occurred. This is also true in Sicily where, after an active subsidence south of the Ragusa platform, pelagic facies with radiolarites occur with pillow lavas. Some changes are also recorded in the trough sediments north of Mallorca, in Morocco and in Greece. Here the existence of continental margins has been recognized (Bernoulli, 1972) and part of the Mediterranean ophiolites could date from this period. Northeastward, the activity of a subduction zone which began at least in the Triassic continued in the Pontids-Caucasus area.
Characterization of the continental margins created at that time is nevertheless still difficult because of the succession of several tectonic phases. Studies in progress by Bernoulli, Marcoux, Bourbon, Lemoine, and Blanchet are resolving this problem.

\section{Late Jurassic (Figure 2[3])}

In the east, the Late Jurassic was a time of intense tectonic activity (Paleo-Dinarides, Dercourt, 1970; Aubouin et al., 1970), with obduction of the ophiolites which were later reworked into the flysch. It is still uncertain whether they are chunks of a true ocean floor or of a marginal basin.

We do not know if the oceanic area that had opened between the Apulia-Anatolia plate and Africa had previously been narrowed with formation of an active margin (formation of the paleo-structures of Mamonia, Cyprus) and a marginal basin where Troodos and Kizil Dag ophiolites originated.

After this period of tectogenesis (late Cimmerian phase) flysch deposits were formed during the Lower Cretaceous (Figure 2[4]) throughout the entire eastern Mediterranean (Beotian flysch, Bosnian flysch, etc.). In the western Mediterranean, physiographic changes were also important. Although there is still no proof of any compression during this time, there is evidence of a very large regression (Purbeckian facies in Spain, South France, Sardinia) and the first flysch deposits were formed during the Early Cretaceous all along the North African margin to southern Italy. This area, on the basis of the reconstitution of the opening of the Atlantic, was up to the Albian (100 m.y.) mainly one of very large sinistral east-west shear zones between Africa and Iberia.

\section{Late Cretaceous (Figure 2[5])}

The importance of the Late Cretaceous tectonic events in the Alpine belt has been known for many years (see review of Argyriadis, 1974). The area was active tectonically from the Pyrenees to the Carpathians and Caucasus, from Haut-Atlas to northern Egypt. At that time the Tethys disappeared. Whereas spreading was active in the northern and southern Atlantic, the Mediterranean area was a region of continental collision between Africa and Eurasia. Following mainly sinistral east-west shear movements during Late Jurassic-Early Cretaceous, there was period of closure between Africa and Eurasia. Intermediate plates such as Iberia, Apulia-Anatolia move independently and would later be dispersed in several microplates. A different type of tectonic activity has prevailed in the Mediterranean area since the Late Cretaceous which we think is similar to the one described by McKenzie (1972), from an analysis of seismicity, as existing at the present time. Paleomagnetic data in Italy indicate a continuing sinistral rotation of these intermediate plates (Klootwijk et al., 1975).

During Albian-Cenomanian time, the Apulia-Eurasia collision is marked by the obduction of ophiolites in the Alps and the beginning of flysch deposition (Helminthoides Flysch). 
The Maestrichtian was the main period of overthrusting in the eastern Mediterranean. In this area we need to recognize the important overthrusts with ophiolitic melanges in the north between the Anatolia and Pontid ranges. These represent the old European edge of the Lias active margin. That subduction occurred is indicated by the existence of andesitic vulcanism during that time-the evidence for which can be followed from the Balkans (Srednogorie Zone) to north of the Lesser Caucasus (Bocaletti et al., 1974; Letouzey et al., 1977)-which remained active until the Eocene. This was the time when the Black Sea emerged as a discrete feature. Moreover we must distinguish the area between Apulia-Anatolia and Africa called proto-eastern Mediterranean or Pamphylian Gulf (Dumont et al., 1972; Biju-Duval et al., 1977) which became a separate arm of Tethys. Large-scale overthrusting occurred which created the Antalya nappes in Turkey, Troodos, Mamonia, and Moni melanges in Cyprus, Kevan, Kizil Dag nappes north of the Syrian platform. These two main structures are merged toward the east in the "Croissant ophiolitique" (Ricou, 1971).

We can speculate that at that time there was still a narrow oceanic area in the eastern Mediterranean and future Tyrrhenian domain. This is the area towards which microplates later moved in response to the constraints of the two main plates.

In the western area, subduction south of Biscay was active along the Pyrennees and may have been active in northern Africa between Iberia and the Tellian domain where flyschs are still deposited ("flysch à microbreches").

\section{Eocene (Figure 2[6])}

Tectonic activity was particularly important during Lutetian (middle Eocene) or late Eocene time. Iberia collided with the African margin which resulted in the ejection of the North-Tellian flyschs: "Mauretanian", and "Massylian" (Delteil et al., 1971) over-thrusts, dispersal of small blocks (Kabylia, Peloritains) initially linked to Iberia, and high pressure metamorphism in Calabria (Dubois, 1970). This collision zone was subjected to major sinistral strike-slip movements, as evidenced by the Atlantic reconstruction. It was one of the main Alpine phases which extended from Corsica to the Carpathians. Such an event is also recorded in the Balkans and Pontids, and in the southern boundary of Apulia-Anatolia whose initial structure was previously completely dislocated. The Pannonian Basin distension is probably also of this age.

The whole western boundary of Apulia, which until that time had been primarily subjected to sinistral shear movement, became a subduction zone. It was the beginning of the formation of the Apennines (Figure 8).

It was after the Eocene that the development of the western Mediterranean began and the geological history of the offshore areas became recorded in the sediments. Consequently, we can rely on more accurate data to surmise the history of the Mediterranean after that time. The eastern Mediterranean, however, can no longer be considered as a recent basin because its southern and eastern margins are as old as Lias or upper Triassic. In the chapter on the eastern Mediterranean we will discuss some aspects of its Mesozoic history.

\section{WESTERN MEDITERRANEAN BASIN}

Seismic reflection data, which are the basis of our knowledge of the western Mediterranean basins, clearly show a general uniformity throughout the whole area from the Miocene until the present time (Mauffret et al., 1973; Biju-Duval et al., 1974). This uniformity is marked by continuous pre-evaporitic deposits, the widespread Messinian evaporites and, a record of a similar Pliocene history. Nevertheless, if we consider the geological setting of the area at the end of the Eocene, two areas can be distinguished.

1) A northern area between Catalonia, Provence, Corsica, Sardinia, and the Balearic Islands. Here the basin developed primarily on a pre-existing craton of Paleozoic formations which were overthrust during the Hercynian orogeny, often onto Mesozoic platform deposits. Only in the Gulf of Lion, Provence, and the Ligurian Sea is the deep basin more or less limited by Pyrennean and Alpine Cretaceous-Eocene folded belts.

2) A southern area which extended from Gibraltar to Sicily where the deep basin was entirely superimposed on a folded belt of Eocene-Miocene age.

These different settings also persist into the postEocene history. In contrast to the northern part, the southern area (South Balearic-Algerian Basin) was contained between the Betic and Maghrebin ranges which were active during the entire Miocene and even up to the present time.

This difference between the North Balearic-Provencal Basin, including the Gulf of Valencia, and the South Balearic-Algerian Basin, including the Alboran Sea, is clearly shown on the map (Figure 1) and the geological cross-sections (Figures 3, 4).

\section{NORTH BALEARIC-PROVENCAL BASIN}

Geophysical data (Figure 5) indicate that most of the margins of this basin are very similar to passive or Atlantic-type continental margins. There is evidence of active horst and graben tectonics during their early history, followed by subsidence and progradation of sediments. Only in Provence and the Ligurian Sea are the margins steep and more similar to strike-slip margins linked to transform faults. This broad similarity suggests that the basin was caused by rifting. We can thus discuss the age of rifting, age of opening, geometry of the opening, and development of the basin until the present time (Figure 6).

Nevertheless, in this comparison with passive margins we must keep in mind that the area involved is very small. We know that the subsided part of the continent on the margins can be very broad, up to 200 $\mathrm{km}$ as in Biscay. Since the distance between the Menorcan and Sardinian shelf breaks is about $300 \mathrm{~km}$, clearly the true oceanic area must have been very narrow and, in contrast to most passive margins, the transition zone covered the greatest area. 

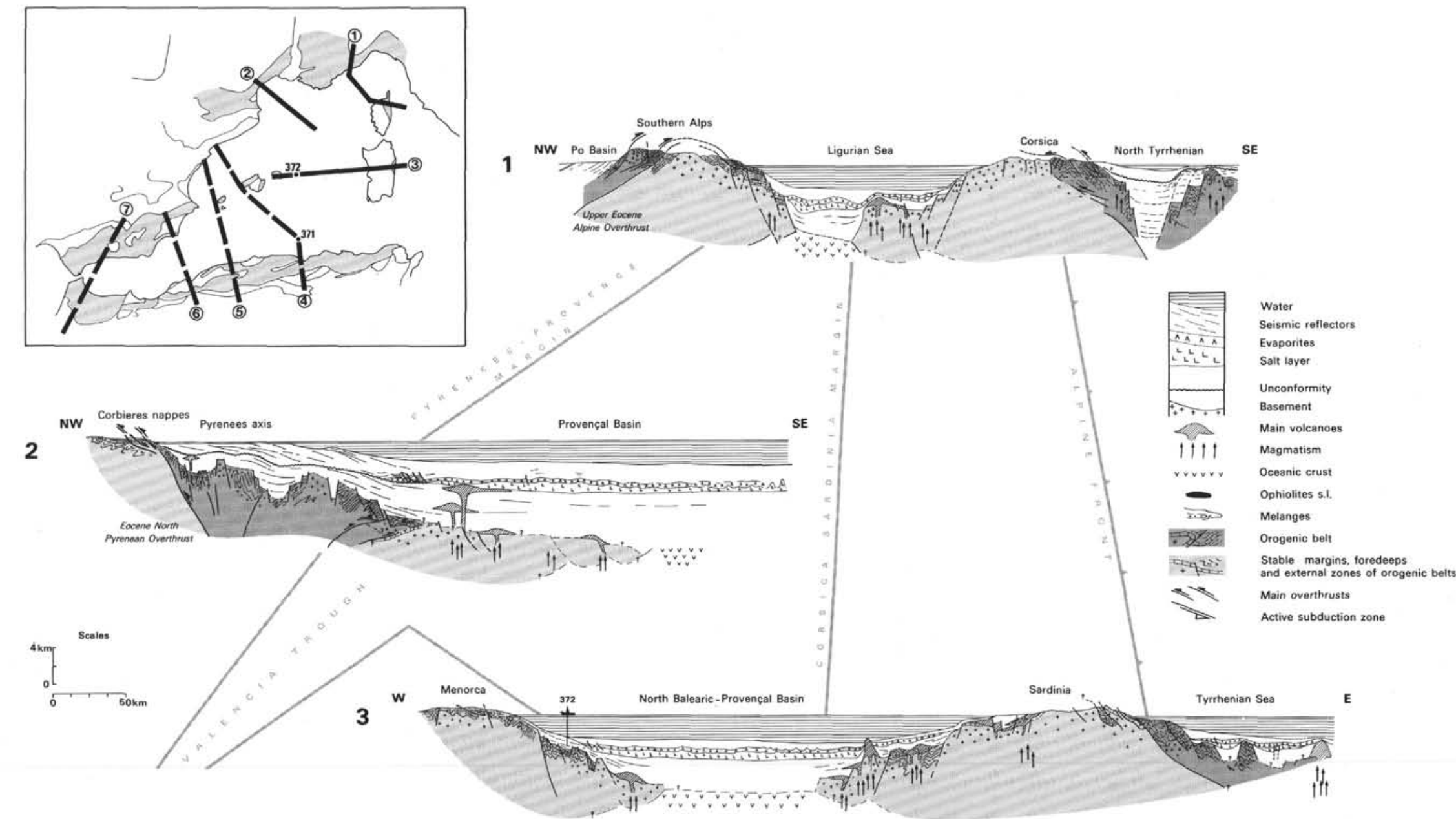

Figure 3. Interpretative geological sections across the North Balearic-Provencal Basin. 


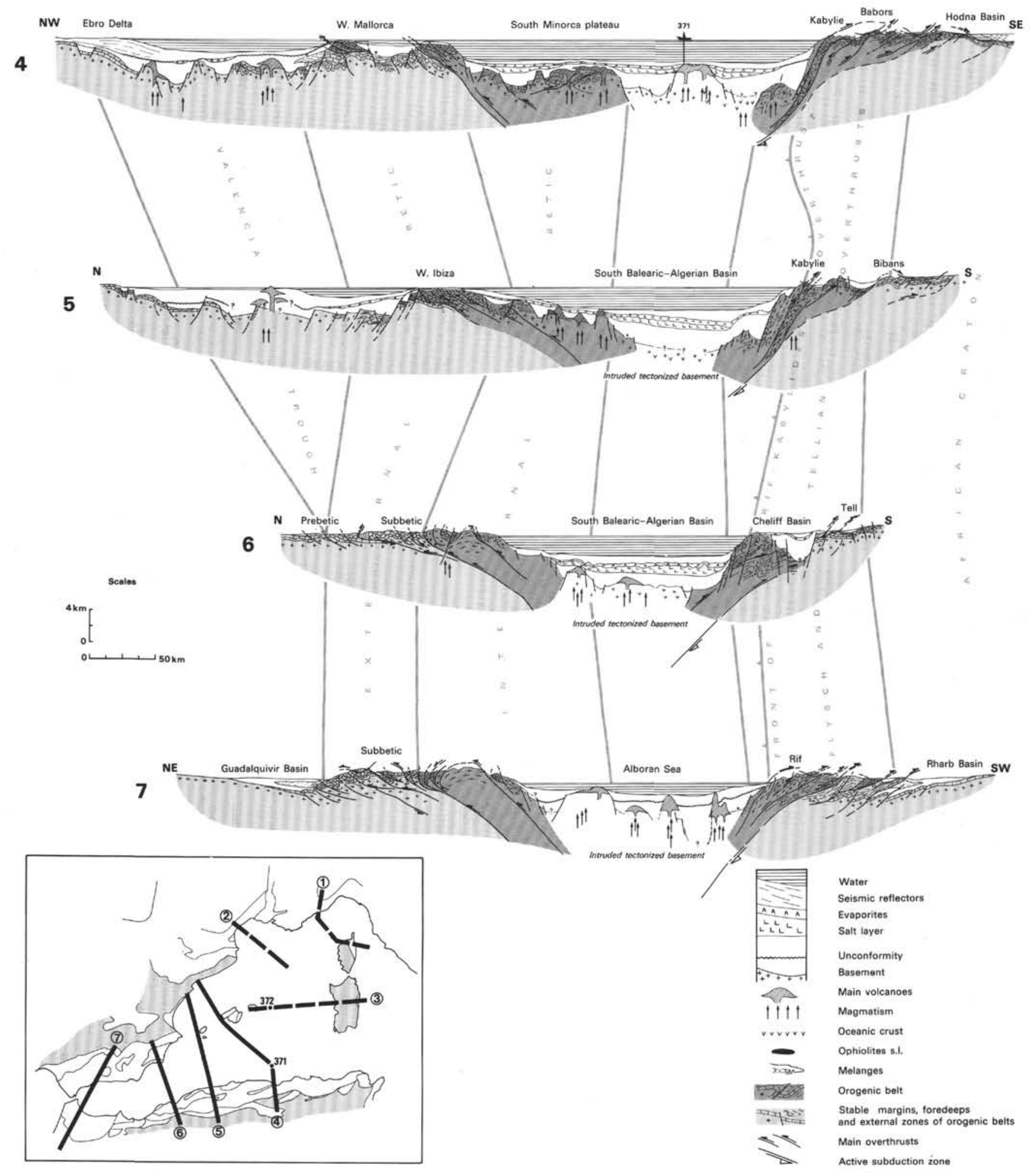

Figure 4. Interpretative geological sections across the South Balearic-Algerian Basin.

\section{Age of Rifting}

Generally, authors agree that the basin originated during Oligocene or early Miocene time. What data are now available to refine this age estimate? It appears that during the Oligocene in Western Europe, including the previous folded areas such as Pyrennees-Provence, many rifts or grabens were created (Rhine Valley, Limagne, Rhone Valley, Languedoc Grabens, Ebro Basin, Manosque Basin, and Catalonia Graben) which received mainly lacustrine-brackish deposits and evaporites. Some of these grabens extended into the Gulf 

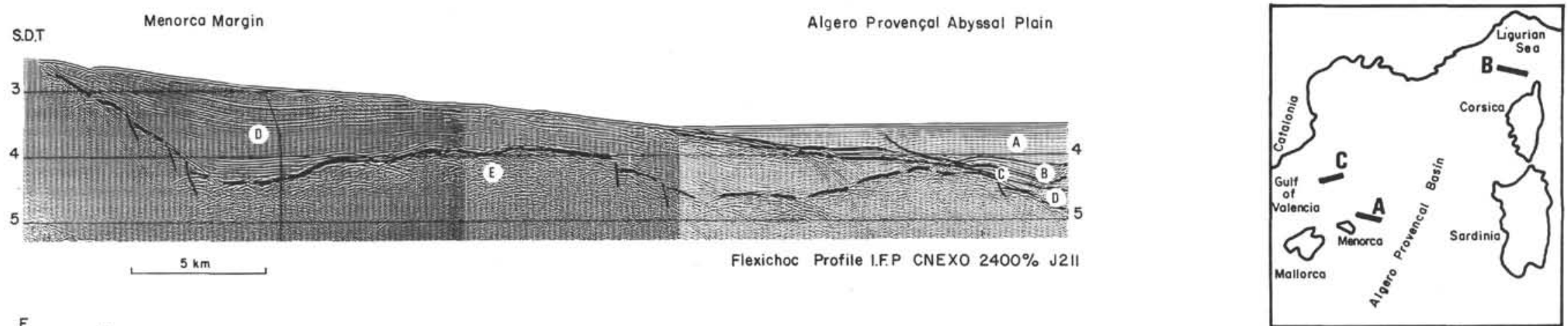

$$
\text { E B }
$$

S.D.T

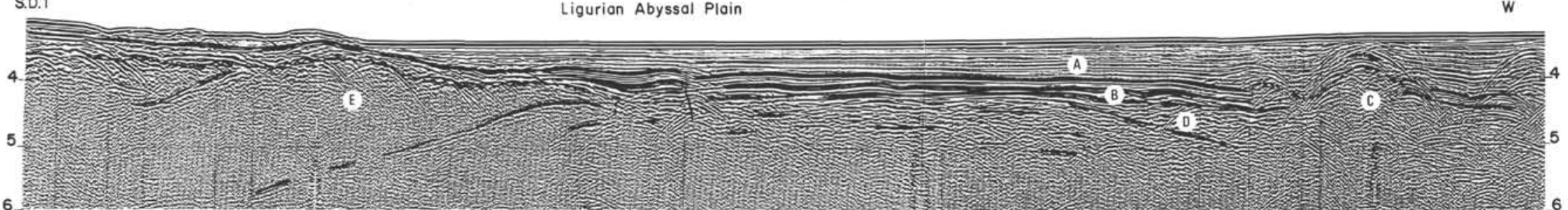

6

Flexichoc Profile I.F.P. -C.N.E.X.0 2400\% J 306
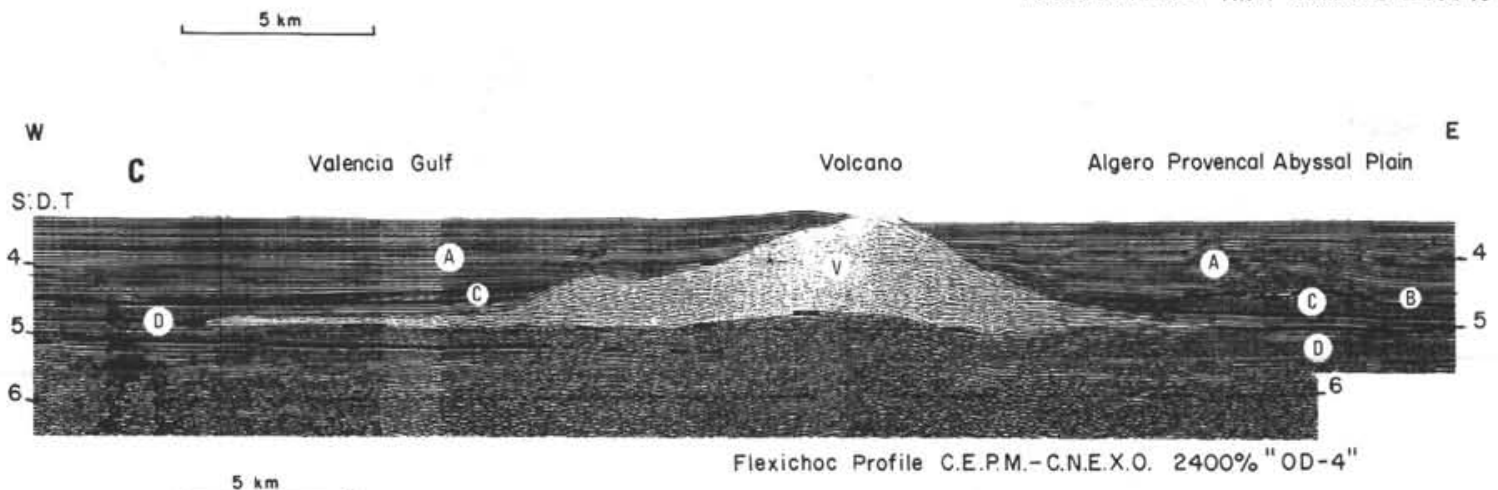

$$
5 \mathrm{~km}
$$

Flexichoc Profile C.E.P.M.-C.N.E.X.O. $2400 \% " 0 D-4 "$

Figure 5. Examples of seismic reflection profiles in the Western Mediterranean.
(4) Pliocene Quaternory

(B) U. Miocene evoporites

(C) U. Miocene solt

(1) Oligo-Miocene infro-solt series

() Poleozoïc and Mesozoï basement

(1) Volcano 

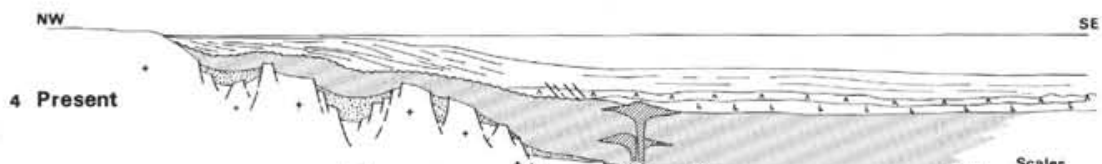

$\varnothing$

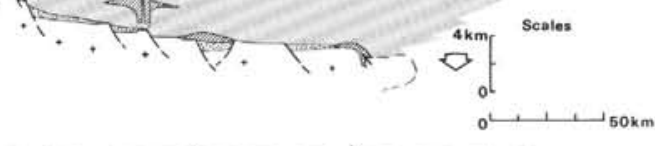

3 Messinian Evaporitic Basin

ic Basin सr. ; 7

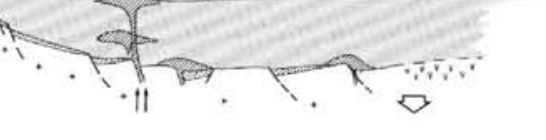

Miocen Early Miocene
Post-opening

$$
\text { सा स्स }
$$

$$
\rightarrow
$$$$
\text { सार }
$$$$
\text { ता }
$$

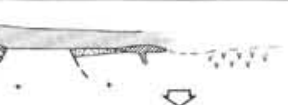

$$
\begin{aligned}
& \text { Oligocene } \\
& \text { Rifting }
\end{aligned}
$$

Figure 6. Tentative geological evolution of the North Balearic Provencal Basin.

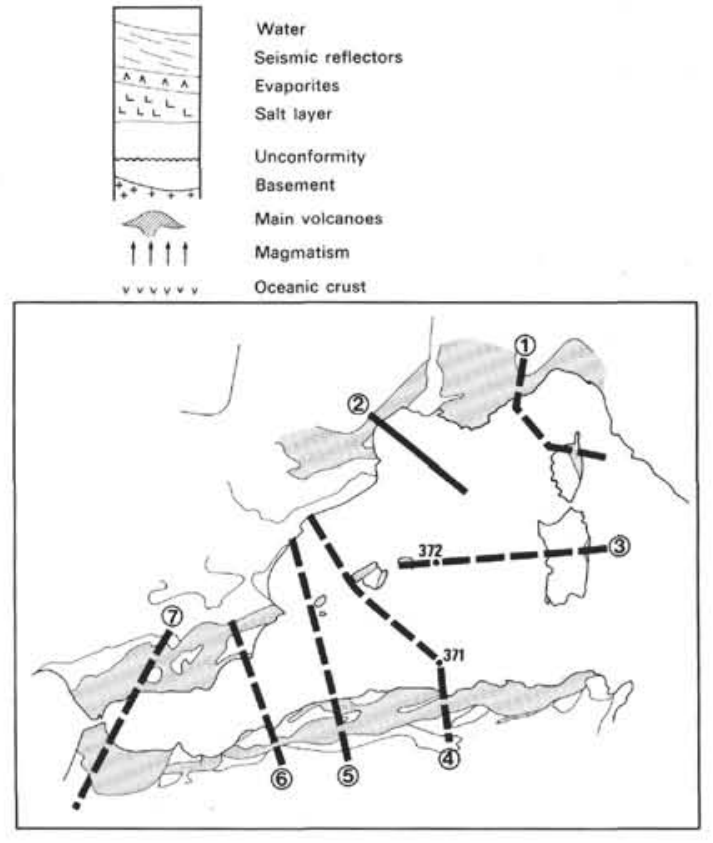


of Lion and the Gulf of Valencia. Marine deposits are known only in active Alpine areas (Annot Sandstones in Provence) and in the Balearic area (Mallorca, Betic ranges, etc.) in relation to the South Balearic-Algerian Basin.

Another approach is to determine the age of the oldest sediments encountered on the margins by studying samples from outcrop or boreholes. In the Gulf of Lion (Cravatte et al., 1974), drilling in the Mistral, Tramontane, and Autan wells encountered basal shallow marine Aquitanian deposits. These results are important because the holes are located on highs or horsts separated by depressions or grabens containing a much thicker sedimentary sequence which, in addition to Aquitanian, must include Oligocene deposits. Marine Aquitanian deposits extend onshore in two small embayments near the Rhone Delta.

Hole 372 on the Menorcan margin was drilled to recover the entire sequence below the Messinian evaporites in a graben which is structurally similar to the other margins of the basin (Figure 3[3]). Because of the absence of re-entry capabilities we unfortunately were unable to reach the basement, but the very lowermost part of the Burdigalian was cored and the seismic profiles show 800 meters of sediments below, filling the graben. In view of this thickness, Aquitanian and Oligocene sediments, perhaps with an evaporitic facies, probably are present below as is indicated by the increasing interstitial water salinity. Reinterpretation of profiles near Site 134 on the Sardinia margin (see Mauffret et al., this volume) suggests that the continental deposits encountered in that hole are sediments related to this rifting phase.

This probable Oligocene-Aquitanian age for the rifting phase is also supported by evidence for intense volcanic activity detected in places: the Valencia Trough (DSDP Hole 123, Ryan, Hsu, et al., 1973), where $21 \pm 2$ m.y. old acidic volcanic tuffs were found, and in Provence and Sardinia. Note, however, that in Sardinia the calc-alkaline succession has been interpreted by Bellon (1976) as possibly related to a subduction zone in the east.

\section{Age of Opening}

Seismic refraction data, although relatively scarce, seem to indicate that part of the North BalearicProvencal Basin is oceanic or suboceanic with a crust/ mantle boundary at about 12 to $16 \mathrm{~km}$ below sea level (Fahlquist et al., 1969; Hinz, 1972; Finetti et al., 1973; Morelli, 1975). Gravity data (Morelli, 1975) are in accordance with this interpretation. Thus, geologists generally agree that the deepest part of the North Balearic-Provencal Basin has an oceanic floor created by spreading with drifting of the Corsica-Sardinia block. If spreading did occur, we need to determine the age of the opening of the basin.

Several approaches can be used to determine the end of the rifting or the initiation of drifting. We may attempt to determine the age of the oldest sediments on the oceanic crust near the margin. This, however, is impossible by drilling in the basin, because of the great thickness of the sediments.

We could also determine the age of the sediments on the margin which are no longer involved in the horst and graben tectonics of the rifting phase, and correlate reflectors of known age on the margin with reflectors in the deep basin. On the margin of the Gulf of Lion, Aquitanian deposits exist on highs or horsts, and seismic reflection profiles show that horst and graben tectonics affect only the deepest layers. Correlation based on wells on the shelf seems to indicate that layers of Aquitanian age are not affected by the horst and graben tectonics and hence rifting had ceased by that time.

On the Menorca margin, near Hole 372, it is difficult to determine solely from seismic data exactly when sedimentation was no longer disrupted by the horst and graben tectonics. There grabens may not have been filled at the end of the rifting phase and/or the horst and graben tectonics may still have been active after the opening.

Nevertheless, results of Hole 372 indicate that there is a sharp break between the upper and lower Burdigalian both in lithology and in sedimentation rate which was very high in the lower Burdigalian. Furthermore, at least the upper Burdigalian section was deposited in a basin which was already relatively deep. Sandy turbidites occur in the lowest part of the Burdigalian. In the adjacent deep basin continuous pre-evaporitic layers which were deposited after the opening are at least 3 to $4 \mathrm{~km}$ thick. Such a thick section may well include the lower Burdigalian which had a high sedimentation rate. This suggests that the opening had already taken place by lower Burdigalian time.

A third approach is to consider indirect evidence for the age of the drifting phase. Such evidence is given by the age of the North Apennine compressional tectonics. Haccard et al. (1972) show that over-thrusting towards the east, in the area of Toscana, began during the Aquitanian while continuous sedimentation occurred in the western Po Basin. If this is related to the drifting of the Corsica-Sardinia block, it implies that the basin was actively opening during the Aquitanian.

In conclusion, there is no absolute evidence of the age of the drifting phase, but it appears that opening occurred during a short period during the Aquitanian and possibly lower Burdigalian time.

\section{Geometry of Opening}

Several models have been proposed by authors who believe that there was a drifting of the Corsica-Sardinia block. A conventional model suggests a single $40^{\circ}-50^{\circ}$ counterclockwise rotation of the block with a pole of rotation close to the Gulf of Genoa. The authors used bathymetric assemblages and paleomagnetic data to arrive at this conclusion (Carey, 1958; Nairn et al., 1968; Alvarez, 1972; Le Pichon et al., 1971; Westphal et al., 1973). In this model Corsica is closed to Provence and Sardinia is closed to the Gulf of Lion. Data obtained from field work also reinforce the proposed fit 
(Chabrier et al., 1975; Arthaud et al., 1975). These latter arguments are not decisive; they merely confirm the paleogeographic relationship of Corsica-Sardinia to the Pyreneo-Provençal realm without any proof of proximity. On the other hand, paleomagnetic data still appear controversial (Zijderveld et al., 1973). Although that displacement took place after the Permian seems well established, displacement in Spain and Italy during the Miocene is still a possibility. Bobier et al. (1970), Coulon et al. (1974), and De Jong et al. (1973) found a well-marked western declination. Coulon et al. (1974) and Bobier (1974) discussed these results and demonstrated that several hypotheses could explain them, i.e., rotation of Sardinia during the early Miocene, no rotation at all, pole migration during the Oligocenelower Miocene, or double rotation. Thus, at present there is no firm proof of rotation from paleomagnetic data.

Another model was proposed by Auzende et al. (1973) and Bayer et al. (1973) on the basis of a new and very accurate aeromagnetic map of the north Balearic-Provençal Basin in conjunction with structural considerations. The main difference is that they postulated that a large fracture zone existed between Corsica and Sardinia which consequently were not considered as a single block. This fracture caused a great differential movement between the two islands. No great degree of rotation of Corsica and Sardinia is inherent in the model.

Presently, because greater seismic coverage has allowed more accurate delineation of the margins, new constraints must be considered in any pre-drift reconstruction.

The isobath map of the acoustic basement (Figure 7) shows, in particular, a broad extension of Corsica below the Ligurian Abyssal Plain; a southeastern prolongation of the margin near Toulon (Provence); a broad extension of the margins of western Corsica and Sardinia; steep linear escarpments which could indicate strike-slip margins related to southwest-northeast transform faults, especially in the Ligurian Sea. These data demonstrate that precise reconstruction on the basis of only bathymetric contours (Westphal et al., 1973) is insufficient.

Seismic reflection data show a good relationship between the main magnetic anomalies and volcanoes. This is particularly evident in the Valencia Trough which is thought to be a rifted basin of the same age as the Provençal basin, but in which drifting did not occur but only subsidence and attenuation (Hinz, 1972). The volcanism was of different ages: between the Aquitanian (Ryan, Hsü, et al., 1973), Messinian (Biju-Duval et al., 1974), and even Quaternary (Mauffret, 1976). Strong anomalies in the Gulf of Lion, South Provence margin, Ligurian Sea along Corsica, and southwest Sardinia are also interpreted as extrusives or as deep intrusions in the crust.

In the deep basin it is evident that quiet magnetic zones delineate the subsided continental crust. This spectacularly extends Sardinia to the west (Bayer et al.,
1973). This is true also in a broad area south of the Gulf of Lion. However, some areas with magnetic anomalies similar to the one existing in the deep basin are clearly on a continental substratum (Corsica and North Sardinia). Moreover, in the deep basin no clear indication of linear anomalies are known except possibly in the very southern part southwest of Sardinia (Bayer et al., 1973).

All these features add new constraints and make it difficult to accept the previously proposed reconstructions. Whereas, some drifting of Corsica-Sardinia is accepted, a pre-Miocene fit is considered most likely that has a restricted (about $100 \mathrm{~km}$ ) east-west translation of Corsica-Sardinia (Figure 8) with little rotation. This is a simplified concept, and it is possible that CorsicaSardinia did not act as a single block but that some distension occurred between them at the level of the Bonifacio straight. This fit implies that a large part of the Gulf of Lion is an attenuated continental crust and that a triple-point junction existed at the eastern entrance to the Valencia Trough during the rifting phase. As in Bayer's model, there is no significant rotation of Corsica-Sardinia. Thus this model will have to be abandoned if further studies demonstrate rotation occurred. On the other hand, the relatively small displacement proposed is in agreement with the probable short period of time during which opening occurred.

We emphasize that the fit proposed is closer in agreement with the structure of the Menorcan margin. Fits previously proposed considered a feature called the "Accident Nord Baleare" at the entrance to the Valencia Trough as an indication of a northwestsoutheast fracture zone-a southern trace of the movement. Instead new data show that this structure is complicated by transverse features which are oriented northeast-southwest from the North Menorcan margin (see Figure 7). Moreover, all around Menorca, the horst and graben tectonic features are well represented on the margin without any indication of a northwestsoutheast shearing. This fit leaves the southern part of the North Balearic Provençal Basin open. The northwest-southeast linear positive magnetic anomaly between Menorca and Tunisia (Figure 7) corresponds to the southern limit of the oceanic area created by translation of Corsica-Sardinia.

Thus, the creation of this southern area must be related to another process. We propose that it is related to the evolution of the South Balearic-Algerian area where subduction, active since the late Eocene, was still active during early Miocene. This will be discussed later with the South Balearic Basin.

In conclusion we emphasize that the question still exists of whether the North Balearic-Provençal Basin, created by the drifting of Corsica-Sardinia, is a true rifted-drifted basin or is a marginal basin related to an Apennine subduction zone to the east that was active during the early Miocene (Haccard et al., 1972) and is marked by calc-alkaline volcanism in Sardinia. After the early Miocene, the spreading area might have 


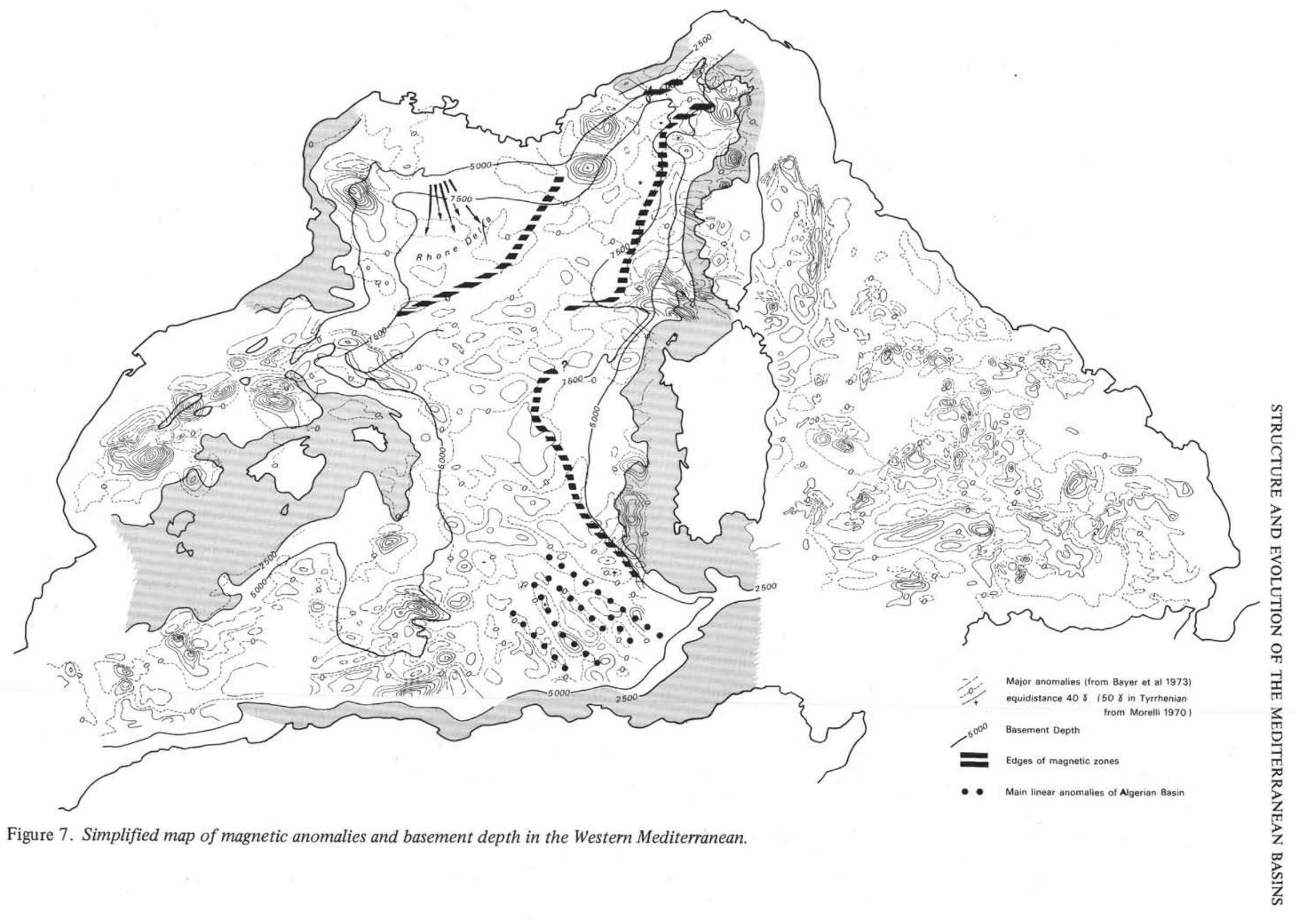




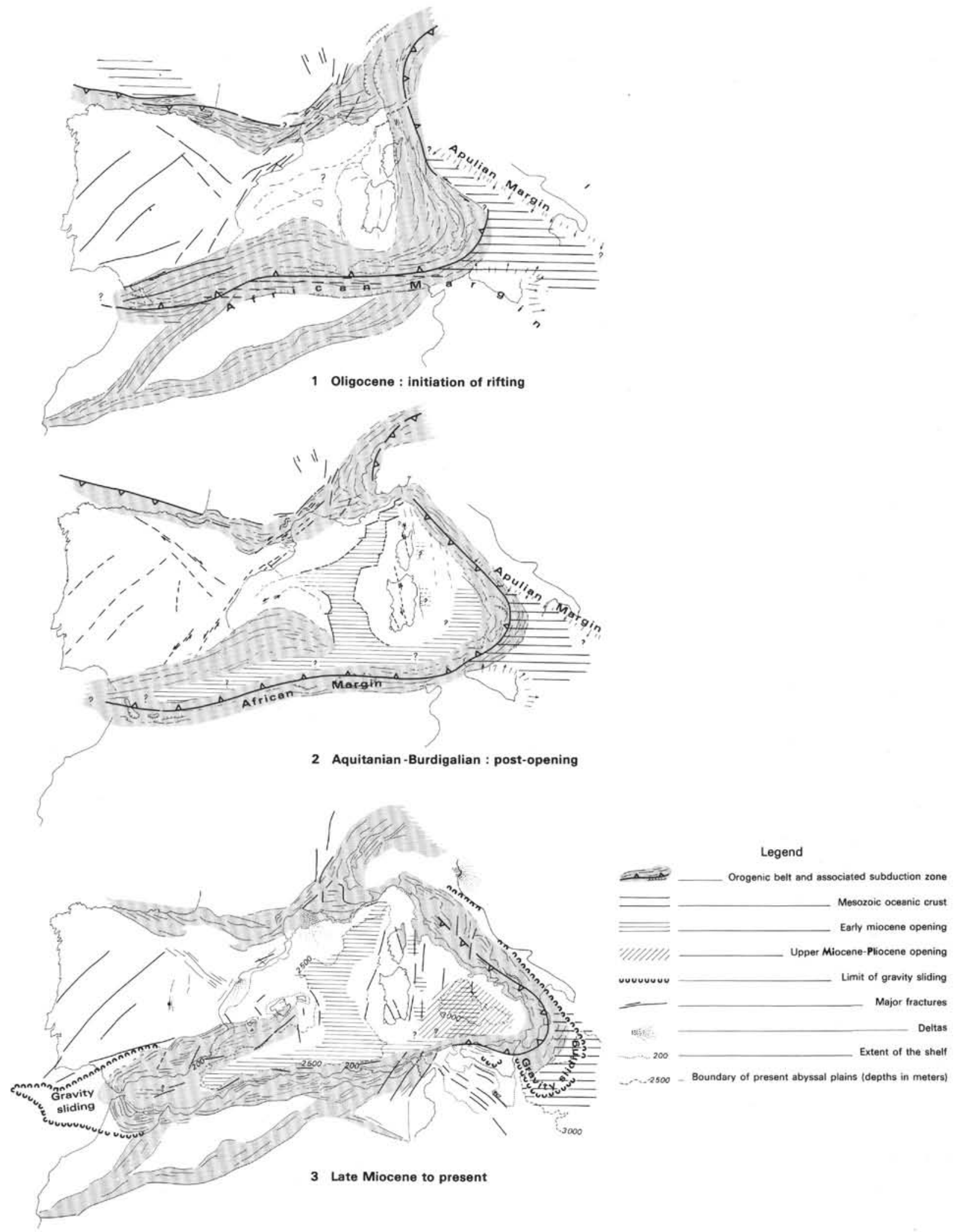

Figure 8. Speculations on the Neogene structural history of the Western Mediterranean. 
jumped to the Tyrrhenian Sea separating Calabrianorthern Sicily from Corsica-Sardinia in a way similar to that proposed by Alvarez et al. (1974).

\section{Development of the Basin to the Present Time (Figure 6)}

We present here only a summary of the evolution of the basin; it is discussed in more detail by Montadert et al. (1977).

\section{Pre-evaporitic "Deep" Basin}

Seismic profiles indicate that a thick sequence (up to 3 or $4 \mathrm{~km}$ ) of horizontal layers exists below the evaporites in the basin (Mauffret et al., 1973) as shown in Figure 3.

Near the margins, there are sedimentary wedges in several places which thin out toward the basin and indicate that different levels existed. These levels are also marked by numerous Oligocene-early Miocene escarpments on which pinched-out Miocene beds are evident. This clearly demonstrates that during that time a relatively "deep" basin existed (about $1000 \mathrm{~m}$ ).

Direct evidence for the existence of a deep basin was found at Hole 372 on the Menorcan margin (see Wright, this volume). Here the benthic fauna indicate that deep conditions $(\sim 1500 \mathrm{~m}$ ?) prevailed during the Serravallian on the abyssal plain, while neritic shallow water deposits were being deposited on the upper part of the margin throughout the entire Miocene on Menorca (see Bizon et al., this volume), on the shelf of Gulf of Lion (Cravatte et al., 1974), in Corsica (Orszag, 1975), and in Sardinia (Pomesano-Cherchi, 1970). Thus the geophysical and Hole 372 data clearly indicate the existence of a pre-evaporitic basin.

Moreover, transgressive upper Burdigalian sediments in Hole 372 may correspond to transgressive sediments found on land. Indeed, it is well known that Burdigalian-Langhian deposits are transgressive all around the basin (Balearic Islands, Rhone Valley, Corsica-Sardinia) and even along all the Mediterranean margins (Biju-Duval et al., 1974).

\section{Late Miocene Evolution}

Seismic profiles (see geological cross-sections in Figures 3 and 4 ) show that the upper evaporitic sequences onlap the thick salt layer of the basin and extent farther in marginal areas. A very well defined erosional surface can be traced along the margins towards the basin until it reaches the pinched-out salt layer. It probably corresponds to a subaerial process linked to a major regression on the margins while the salt layer was being deposited in the basin during a low level stage (Figure 6). The upper evaporitic sequence was deposited on this erosional surface. This is described in greater detail by Montadert et al. (1977). A shallow depositional environment, for the upper evaporitic transgressive layers could also explain some local erosion of these upper evaporites. During this significant regression, the depositional conditions of the thick homogeneous salt, which fill the major depres- sions, are not fully understood and the presence of infrasalt evaporites is still doubtful. Active subsidence continued during evaporite deposition.

\section{Pliocene-Pleistocene Subsidence of the Basin}

The "Pliocene revolution" of Bourcart (1963) or "Ponto-Plio-Quaternary" of Glangeaud (1971) is now the subject of much discussion. Knowledge of the widespread distribution of evaporites shows that the initiation of the subsided basin was older (at least late Miocene). We have seen previously, from geophysical evidence and Site 372 data, that the western deep basin was in fact in existence since at least Burdigalian time as previously shown by Mauffret et al. (1973) and otherwise discussed by Le Pichon et al. (1972).

Nevertheless, the subsidence of the basin was continuous and is still active today. The occurrence of Pliocene-Pleistocene vertical movements cannot be denied (Bellaiche et al., 1974; Burollet et al., 1974; Stanley et al., in preparation). They are part of the subsidence history of the basin and probably resulted from the cooling of the oceanic lithosphere and the loading of sediments. Prograded deposits on the margin enable us to estimate the subsidence at 1500-2500 meters. Subsidence was either in the form of tilting (Gulf of Lion) or marked by tilting and faulting (evaporites were often shifted several hundred meters as for example in Liguria and the Gulf of Valencia).

Intense halokinesis has been described, but two observations are especially significant. Although the thick salt layer was practically inactive or with the formation of only a few large domes in some parts of the basin (southeast Gulf of Lion), in the other parts of the deep basin numerous piercing diapirs developed. The boundary between the two areas coincides approximately with boundary of the oceanic crust as proposed above in our model. Secondly, the area where diapirs are numerous is affected by Pliocene vertical faulting which accentuates the complexity of the halokinesis. The meaning of this tectonic event is not clear. It could be linked to the subsidence history and/or to a particular tensional event, perhaps in relation to the formation of the Tyrrhenian Sea.

\section{SOUTH BALEARIC-ALGERIAN BASIN}

From the previous considerations about the historical evolution of the Alpine area and from geological sections, it appears that the South Balearic-Algerian Basin is located in a divergent orogenic belt (Betic and Maghrebian ranges). Nevertheless, in this unit several areas are distinguished.

1) The Alboran Sea (Figure 4) is characterized by the absence of thick evaporites and the occurrence of numerous volcanic highs clearly expressed in the topography.

2) The South Balearic Basin sensu stricto (Figure 4 ) is characterized by a thick salt layer and numerous magnetic anomalies which are probably related to the volcanic deposits. 
3) The South Menorcan marginal plateau (Mauffret, 1976) has a large magnetically quiet northern part and a narrow southern part with magnetic anomalies which, as demonstrated by the relation between anomalies and seismic highs, are probably related to volcanoes (Gonnard et al., 1975). Drilling at Hole 371 was planned to investigate this magnetic basement but did not penetrate through the Messinian gypsum.

4) The southern part of the so-called North Balearic-Provencal Basin is characterized by a thicker sedimentary section; the salt layer is well developed and the magnetic anomalies are relatively well lineated.

From seismic reflection profiles (Figure 4) basin filling is similar to that of the Algero-Provençal Basin, but we cannot assume that the age of the pre-evaporitic section is exactly the same. Furthermore, the structural setting is different. After the Eocene (Figure 9 ) it is possible that an episutural basin (Bally, 1975) was superimposed on the pre-existing structure. Because of relative movement of Iberia and Africa on each side of the Azores-Gibraltar fracture zone, the opening of this episutural basin is probably complicated by strike-slip faults. Then during the Oligoceneearly Miocene, compression continued which caused the ejection of the Numidian flysch as nappes in the Maghrebian range. This indicates that tightening of Africa against Iberia continued after their collision in the Late Cretaceous(?)-Eocene time. Then during Miocene times, perhaps since the Burdigalian as indicated by field evidence and results of offshore drilling (Burollet et al., this volume), the basin began to take on its present configuration. Nevertheless, the area as a whole was still subjected to compression as evidenced by overthrusting which occurred continuously in the Betic and Maghrebian ranges on both sides of the basin.

The Maghrebian range was continuously tectonically active until the Quaternary. The main deformations happened during Tortonian time and included formation of large gravity nappes. In the Betic range deformation continued until after the Langhian. Gravity slides occurred in the external zones (Guadalquivir Trough, Atlantic Ocean, front of the Sub-betic, and perhaps in the Southern Valencia Trough). In the Balearic Islands except Menorca, post-Langhian overthrusting was intense, but Tortonian deposits were not affected.

We first conclude that the South Balearic Basin has remained undisturbed since the Burdigalian while on both sides of the basin overthrusting continued to be active. This is true even during the Quaternary when strong compression occurred in Tunisia (Burollet, 1967; Coque et al., 1965), less in Algeria (Thomas, 1974), and no compression occurred in the deep basin as evidenced by lack of compressional features on the seismic profiles.

Note that seismicity is active along the North African margin, but the geological sections (Figure 4) show that it does not correspond to an active subduc- tion of the South Balearic Basin under Africa as suggested by Auzende et al., 1973. This very recent tectonic activity is not so intense in Spain as in the Gibraltar area where mainly strike-slip faulting and vertical movements have been described (Bousquet et al., 1974).

In relation to this compressional history, intense volcanic activity occurred between Gibraltar and Sicily, including Sardinia. According to Bellon (1976), deposition of compressive calco-alkaline volcanic rocks began during the Aquitanian-Burdigalian in Sardinia and in some places in Sicily, in Algeria and in Southern Spain, as indicated by tuffite layers in the Numidian flyschs or the equivalent beds (Wezel et al., 1973). After the flysch ejection this compressive calco-alkaline volcanism continued mainly during the Serravallian and Tortonian from Gibraltar to Tunisia and also in Sardinia and southern Spain. Granitization occurred at that time in Algeria and Tunisia and even in southern Sardinia. This calc-alkaline volcanism ceased before the Messinian except in northern Morocco. Instead, throughout the entire Mediterranian area, a basaltic extensional volcanism occurred. Note that these considerations on volcanism are on the basis of land data only; the very large areas of volcanics on the margins and in the deep Balearic Basin are practically unexplored.

In conclusion the South Balearic Basin appears as a kind of marginal basin located inside a divergent orogeny, where attenuation, creation of oceanic crust (Hinz, 1972) and volcanism occurred while compression was still active on both sides. In this divergent orogeny, the subduction zone (subduction B in the sense of Bally, 1975) was situated in North Africa and dipped to the north. On the other side, the northward overthrusting probably does not have the same significance as subduction A (again in the sense of Bally 1975).

In this setting, the interpretation of what is found in Hole 372 appears clear. Our present understanding of land geology and of the deep marine basins from geophysical data and from Hole 372 data explain one of the most puzzling problems of the western Mediterranean, i.e., the termination of the Betic range east of the Balearic Islands. Until now the structure of Menorca has always been considered as a simple extension of the external Betic range with the last important overthrusting occurring after the Langhian. In reality this phase is well defined in Ibiza and Mallorca, but no evidence suggests that it exists in Menorca.

Hole 372 shows that the rifted margin of Menorca is related to the creation from the Oligocene to the Burdigalian of the North Balearic-Provençal Basin. At the time of overthrusting in Ibiza-Mallorca, the oceanic part of the North Balearic-Provençal Basin had already been created. East of Menorca, absence of any indication of compressional tectonics or any break at that time, permit us to interpret the existence of a divergent orogeny and the limited extension to the east of its northern segment (Betic Range) as evidenced by the fact that such a feature occurred because on both sides 


$$
\begin{aligned}
& \text { Eocene } \\
& \text { Jurassic } \\
& \begin{array}{l}
\text { Triasic } \\
\text { Cretaceous }
\end{array} \\
& \begin{array}{llll}
\text { EU : Europe } & \text { B: Biscay } \\
\text { AF : Africa } & \text { T: Tethys }
\end{array}
\end{aligned}
$$

N
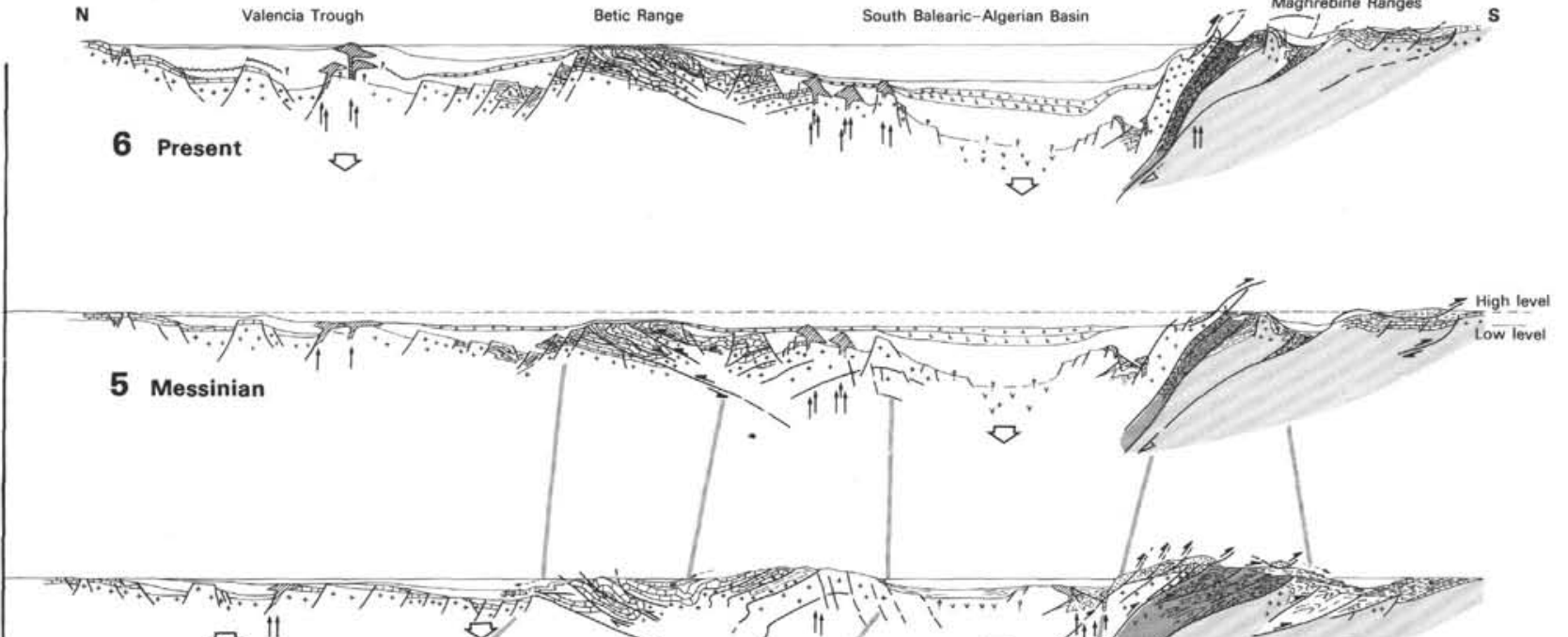

4 Early Miocene :- backward thrusting (after southward flysch ejection)

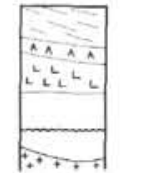

Seismic reflectors
Evaporites
Salt layer
Unconformity
Basement

Main volcanoes

111 Magmatism

Oceanic crust

-

xxpres:

Main overthrusts

A. Active subduction zone

Cz Cenozoic

Mz Mesozoic

Gravity sliding

N.

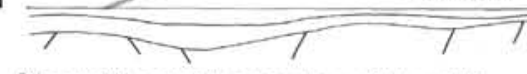

Mesozoīc : small extension of the Tethys

3 Oligocene-Aquitanian : formation

of western Mediterranean

(eastern extension of Azores-Gibraltar f.z.)

Figure 9. Tentative geological evolution of the South Balearic-Algerian Basin.

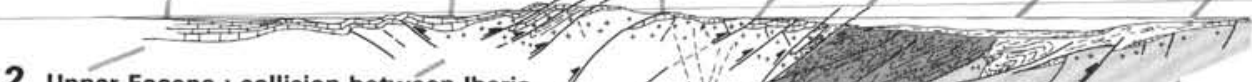

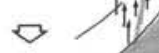


only a continental crust existed and was colliding, while to the east an oceanic crust already existed (Figure 8).

\section{EASTERN MEDITERRANEAN AREA}

The geological setting of the eastern Mediterranean Basin is very different from that of the Western Mediterranean Basin. The Eastern Mediterranean is superimposed southward on the stable African margin and northward on the active Alpine margin. As shown in the outline of the geological history, this situation is as old as Late Cretaceous when the ophiolitic melanges belt of Cyprus-Taurus was emplaced. Nevertheless, as discussed previously, the existence of a stable margin along Africa is probably older. The structural map (Figure 1) and the interpretive geological cross-sections (Figure 10) show this striking opposition between the north and south eastern Mediterranean.

There are still numerous uncertainties in the geology and geophysics onland and offshore. Therefore any interpretation of the area is still very speculative. For this reason it is difficult to describe the geological evolution for the entire area step by step. So we will discuss the geology of the area, beginning first with the southern stable margin and the adjacent deep basins, followed by the different active folded arcs in the North such as the Cyprus Arc, the Aegean Arc and Mediterranean Ridge and the Calabrian Arc. Indeed each of these arcs has its own evolution, as will be explained.

\section{SOUTHERN AND EASTERN STABLE MARGINS AND DEEP BASINS}

\section{Geophysical Evidence}

Geophysical interpretations on the basis of gravimetry and some refraction data show that the deep abyssal plains of the eastern Mediterranean are located on top of a thick sedimentary cover which lies on a thin crust that is intermediate or oceanic and thickens progressively southward toward the African continent. We have no direct evidence of the age of formation of this thin crust. There are no magnetic anomalies in the deep basin. The seismic reflection profiles show a very thick sedimentary cover which probably includes the Mesozoic series. As opposed to the western Mediterranean and Tyrrhenian Sea, magmatism is restricted to only some areas (Gonnard et al., 1975). All this indicates that no important opening has occurred since the Cenozoic and perhaps not since the latter part of the Mesozoic, and that the history of the eastern Mediterranean is completely different from that of the western Mediterranean. This view is compatible with the continental reconstructions established on the basis of Atlantic data (Figure 2). Thus we need to find geological evidence of the early continental margins north of Africa-Arabia.

\section{Geological Evidence of the Old Age of the Margins}

As in the case in many of the present stable margins, land data are too scarce to clearly establish the history of the African-Levantine margin. Exposures are mainly of Cenozoic layers, and data for older rocks come from subsurface geology (oil wells); moreover, outcrops and data for each period are located at widely separated locations.

\section{Triassic-Jurassic}

As we have previously noted the upper Triassic-Lias is a period of general distension in the whole Mediterranean-Alpine area. At that time the offshore-SiculoTunisian platform, an extension of the African craton, including the Ragusa Plateau, is marked by limited subsiding basins (for example, the salt Triassic basin; Burollet, 1967), and by the local development of pelagic facies in the neritic carbonate environment. Evidence of volcanic activity can be seen south of Sicily.

The relationships between new and older structural elements, for example, the Permian flexure at Djeffara, are not well understood. Along the Israelian margin there is a quick change of facies westward from a neritic to a pelagic facies. This is particularly true in Jurassic sediments (Ginzburg et al., 1975; Razvalyayev, 1971). Freund et al., (1975) suggested that a small oceanic basin existed which developed between the African continent and the Alpine orogenic belt and was similar to Pacific marginal seas.

South of Turkey, sediments now tectonized into Antalya nappes, are interpreted as remnants of margins created during the Triassic distension into the previous Africa-Apulia craton (Figure 11). In this paper we accept this interpretation first presented by Horstink (1971), Dumont et al. (1972), and Monod et al. (1974), although some authors still suggest a northern origin of the nappes (Ricou et al., 1974). The northward thickening of the Jurassic sediments described in Cyrenaica by Klitzsch (1970) may also indicate a marginal position.

\section{Cretaceous}

Our knowledge of the Cretaceous sediments of northeast Africa does not clearly establish the existence of a previous margin. In the Siculo-Tunisian area, the extension of neritic-platform carbonates shows that this area still represented the extension of African during Cretaceous time.

Is the Malta Escarpment, between the Siculo-Tunisian and Ionian areas, an old feature which was the margin during the Cretaceous, while in the east in the Ionian Sea pelagic oceanic sediments were already being deposited? This escarpment is marked by a series of strong magnetic anomalies and by intense recent faulting which has obscured possible earlier features. Towards the south and southeast, the escarpment is less marked and runs towards Cyrenaica, north of the Syrte Basin. The Syrte Basin is very interesting because inland it is well known to have been subjected to intense distensions from the Cenomanian to the present time (Hon graben). This inland area, marked also by Neogene-to-Recent magmatism, represents an important structure of Africa and was perhaps superimposed 
on a former Precambrian suture zone (east of the panAfrican orogeny). A gentle slope continues from the Syrte Gulf to the abyssal plain, and deep seismic horizons can be followed continuously.

In East Africa, Cyrenaica to Egypt, the Cretaceous series thickens northward which may reveal a marginal setting.

Data on the Levantine margin are much more conclusive because it is now well established that during the Early Cretaceous the present Israeli coastline was already a margin, perhaps initiated in the Triassic (Ginzburg et al., 1976).

The existence of an old oceanic realm, or at least a continent-ocean transition zone, directly north of Africa, has not been definitely proven. But that something similar existed is highly probable if we consider all the data. Nevertheless, an important aspect is that all the North African margin (including the Atlas and Hauts Plateaux area) is marked by Late Cretaceous folding (Said, 1962; Syagayev et al., 1971). In Egypt some southward overthrusts which are oblique to the present margin have been noted by Salem (1976). The significance of these features is not clear but could be a result of Late Cretaceous continental collision (Figure 11). Bear in mind that evidence of compressional tectonic activity far inside continental Africa has been noted for a long time (intraplate deformations).

\section{Cenozoic}

All the margins between northern Tunisia to the Levantine coast are marked by Recent vertical tectonics and prograding systems which implies a recent foundering of the margin.

This foundering is well marked in the upper EoceneOligocene as indicated by geological data, i.e., thick Neogene sequences filling the deep basins. But in contrast to the western Mediterranean magmatism is limited to a few areas.

The main points of interest are:

1) The rift structures in the Siculo-Tunisian threshold. Seismic reflection profiles show that several grabens (Linossa, Pantelleria) were initiated at the end of the Miocene. Numerous faults were caused by volcanic injections and there was a new fragmentation of the northern part of the African block.

2) The Malta escarpment which separated the Ionian Abyssal Plain from the Siculo-Tunisian platform. This is one of the steepest scarps in the Mediterranean.

3) The well-marked progradation north of Syrte and the Recent faulting along the shoreline of Cyrenaica and northwest Egypt.

4) The Nile delta development which was initiated onshore in the late Eocene-Oligocene toward the Quattara depression. The Nile delta suddenly migrated during the lower-middle Miocene to its present position. At the same time, the Red Sea region was rifting (Salem, 1976). Very thick sediments comprising several thousand meters of Neogene-Quaternary sediments filled the Herodotus Abyssal Plain.
5) The Levantine margin was very steep and many new canyons developed in it during Miocene to recent time.

6) The structure of the Eratosthenes Seamount is not very well understood. The thinning of the Messinian evaporites suggests that the Erastothenes mountain was a high at that time. Is it a horst from the African Margin separated from the Levantine Coast by the subsided Levantine Basin? The question still has not been resolved.

All this Cenozoic history of the African margin and of the basin itself was related to the northern development of an active margin which was progressively closed: by the end of the Cenozoic, stable African margins were practically in contact with the active $\mathrm{Al}$ pine margin.

As in the western Mediterranean Basin, the Cenozoic evolution of the different basins is summarized as follows.

1) A pre-evaporitic basin existed which was affected in the north by compression in front of the active margin.

2) Evaporites with a thick salt layer developed in depressions and subsiding basins and the upper part of the evaporites onlapped the highs while compression was still active in the north.

3) Subsidence continued with a large prograding system (Nile cone and Seyhan), and tilting and faulting are active during Pliocene-Quaternary time.

\section{NORTHERN ACTIVE ALPINE MARGINS CYPRUS ARC}

The Cyprus Arc (Figures 10 to 12) runs from south Turkey-north Syria to south of Anaximander seamount through the island of Cyprus. Its structure corresponds to a complex compressional history which began in the Campanian-Maestrichtian by the obduction of ophiolites and continued to the present time. The result is complicated because (1) successive overthrusts are not always located at the same place and have not always disturbed the same previous structure; (2) small basins developed in front of or in back of the main folded zone; and (3) resedimentation phenomena (olistostromes and olistoliths) are very common, as shown by land geology data (see Baroz et al., this volume).

\section{Speculations on the Mesozoic History}

As shown in Figure 2, during the Mesozoic this area was located near the junction between the former Tethys and a southern branch consitituting a protoeastern Mediterranean, which was located south of the Apulia-Anatolia continental block. Schematic crosssections of the area (Figure 12) summarize different hypotheses which have been put forward to explain the evolution of the area since the Late Cretaceous.

\section{Triassic-Lias-Jurassic}

The occurrence in allochthonous units (Baasit in Syria, Mamonia in Cyprus, Antalya in west Turkey) of 


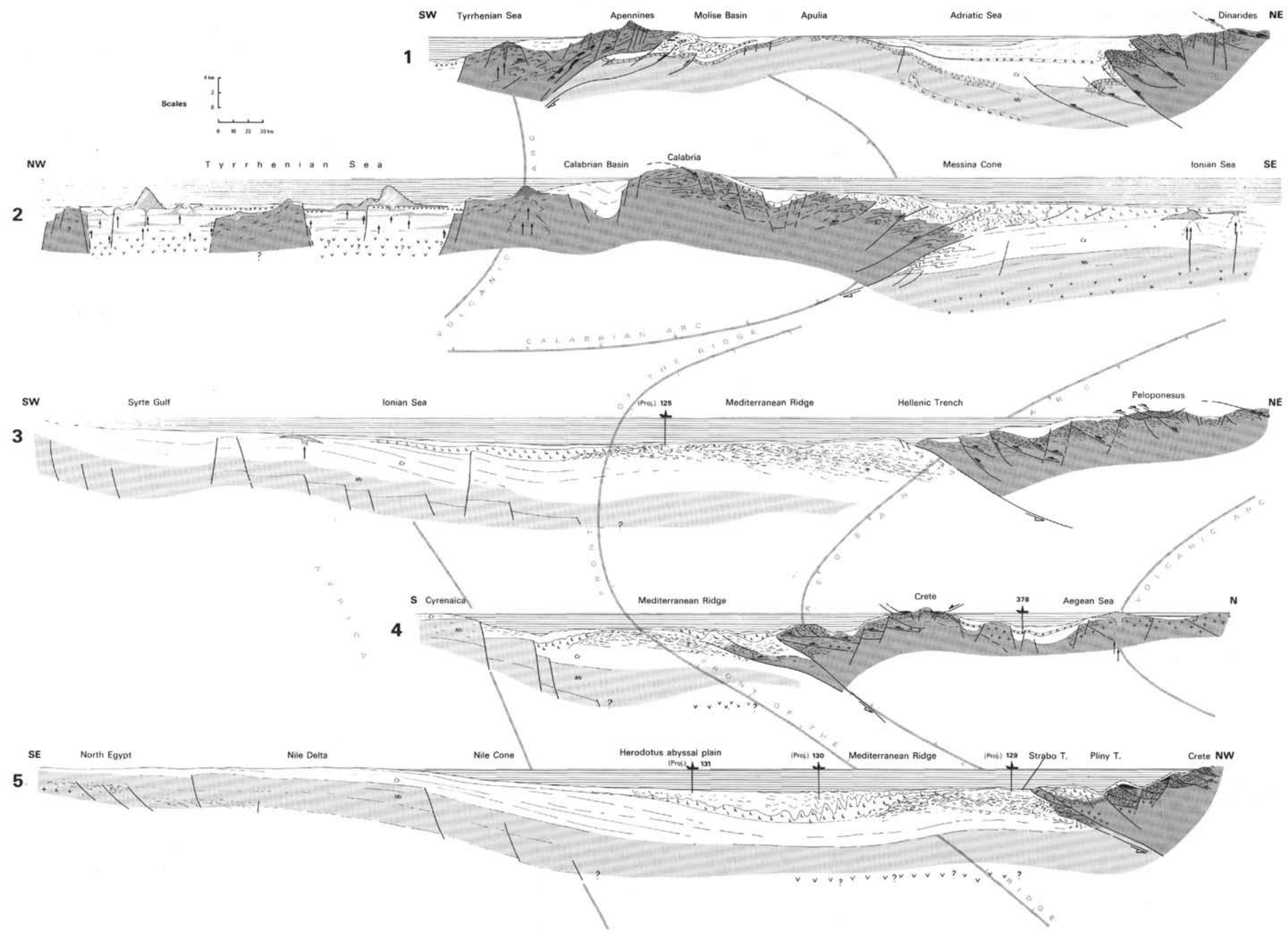

Figure 10. Interpretative geological sections across the Eastern Mediterranean. 

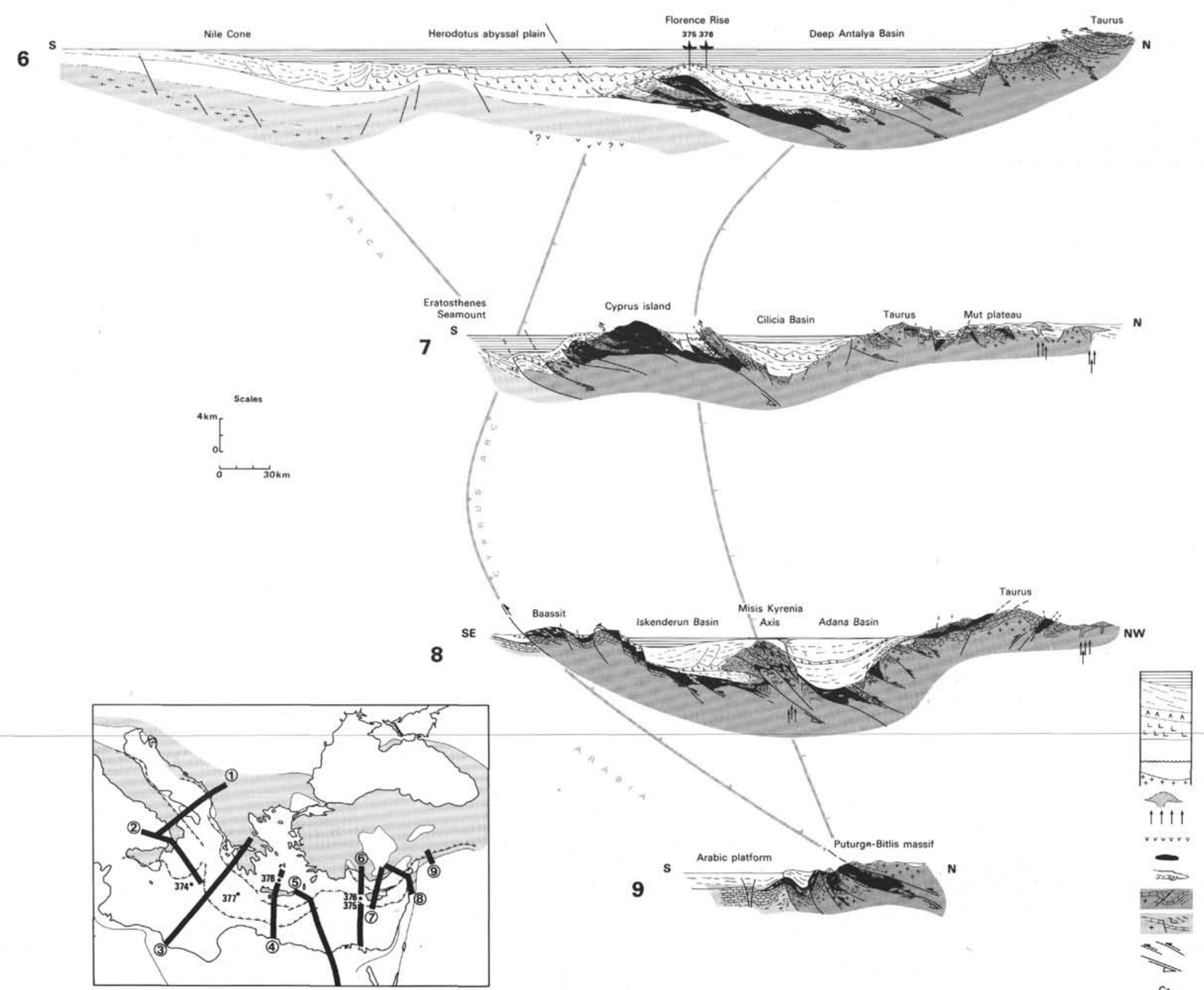

Water Evaporites Salt layer Basement Main volcanoes

iti

I I I Magmatism

1111. Ocaanic crust

- Ophiolites st.

$9 \mathrm{~s}$ Arabic plattorm

Melanges

Orogenic bet

Stable margins, toredeeps

and oxternal zones of orogenic belts

ST Main overthrusts

Active subduction zone

Cz Cenozoic

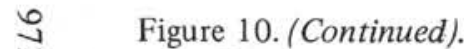



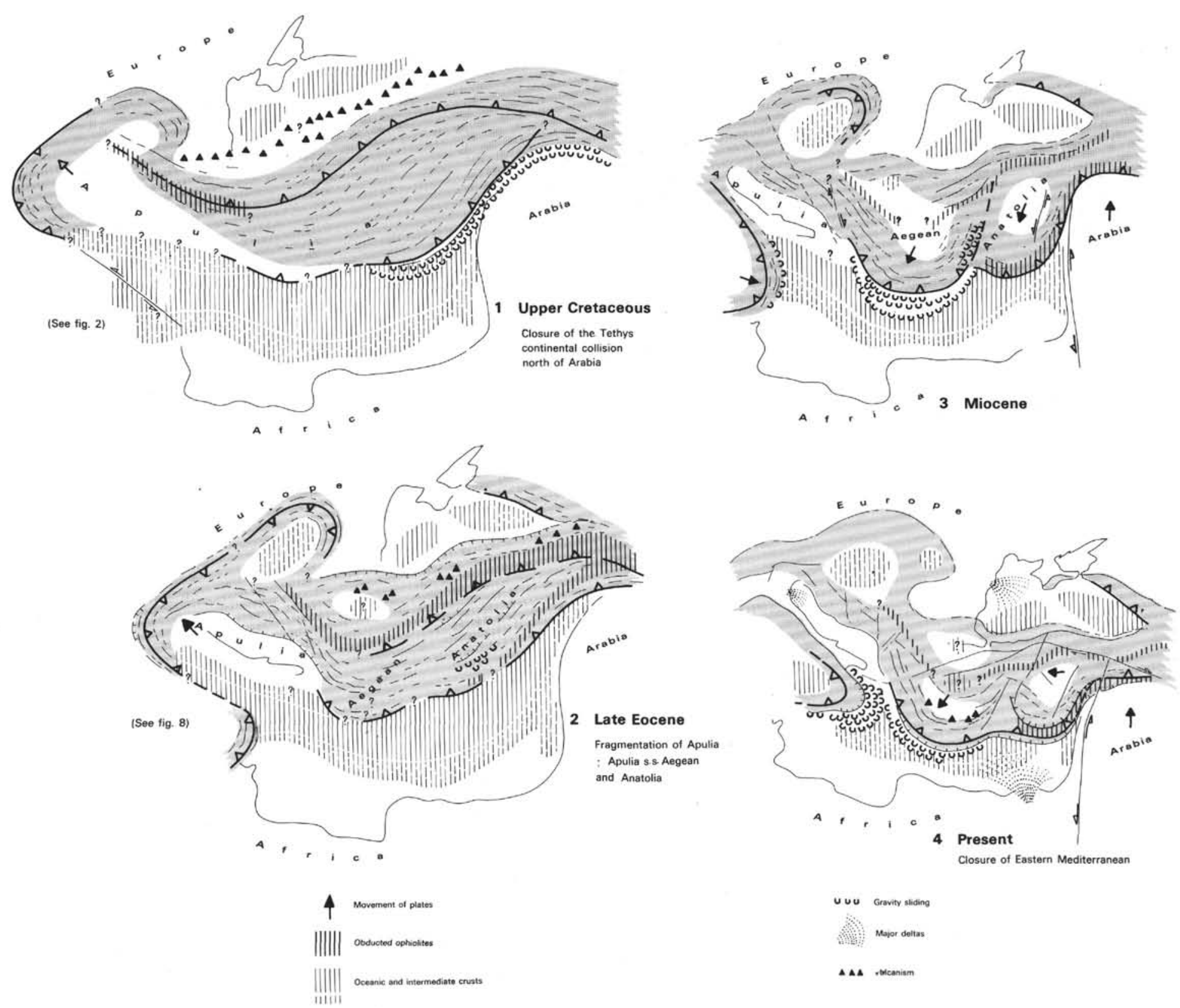

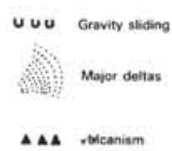

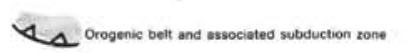

Figure 11. Speculations on the Cenozoic structural history of the Eastern Mediterranean. 
Present

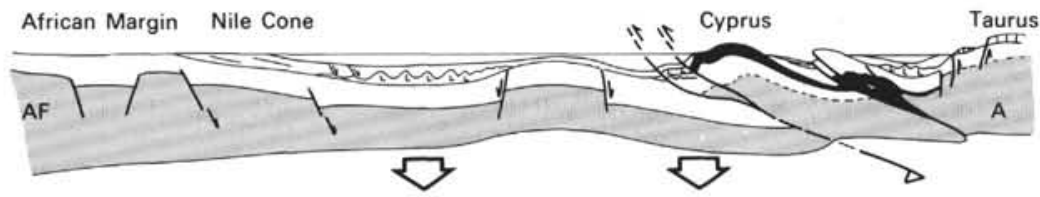

Messinian

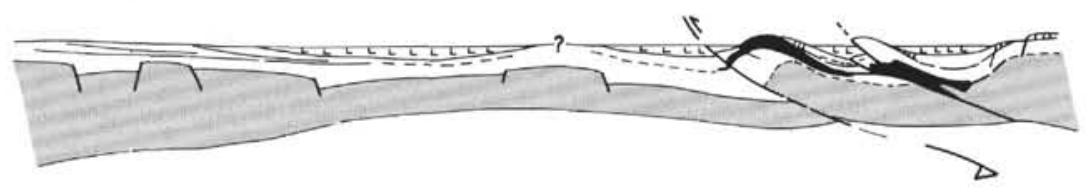

Upper Eocene
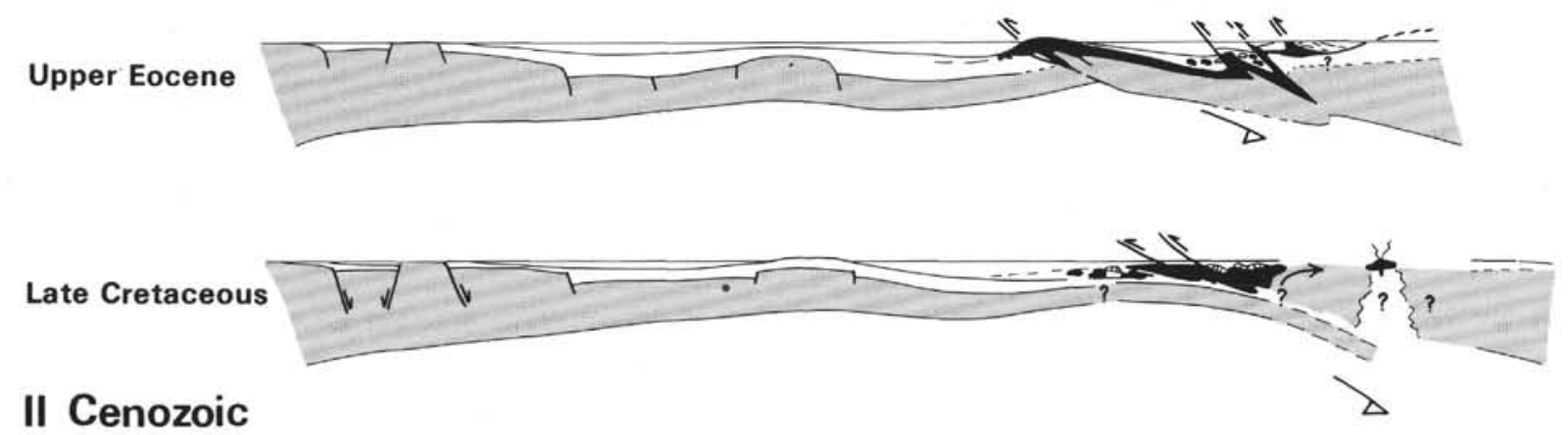

I Mesozoic

A. hypothesis

B. hypothesis

C. hypothesis

D. hypothesis

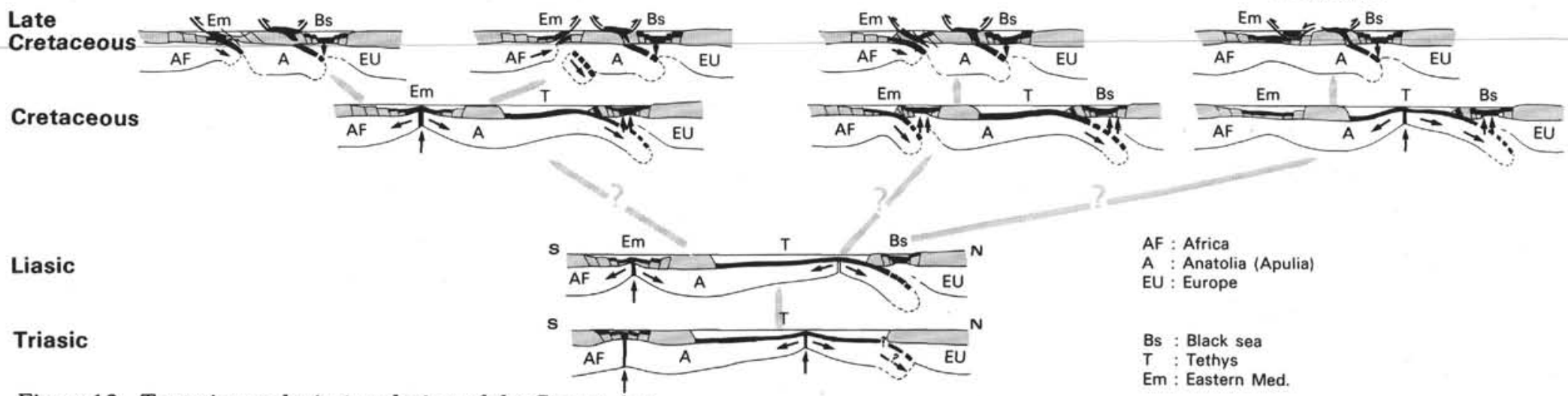

Figure 12. Tentative geological evolution of the Cyprus Arc. 
typical shallow-water transitional to pelagic deposits with pillow lavas is interpreted as characteristic of the development of a stable margin during the TriassicLias-Jurassic.

According to various authors this margin was located either north of the Apulia-Anatolia block (Ricou et al., 1974, hypothesis D) or south and east of this block. We prefer this last hypothesis because, as discussed before, a stable North African margin and a basin probably already existed by that time.

\section{Cretaceous}

The absence of Early Cretaceous sediments in $\mathrm{Cy}$ prus and the Barremian to Campanian age of the ophiolites of Troodos can be explained by two hypotheses.

1) Hypothesis A-B. A spreading ridge is still active at that time in the proto-eastern Mediterranean with, in the Late Cretaceous (Campanian-Maestrichtian), collision and obduction of the normal oceanic crust. Three possible tectonic settings are: an overthrust toward the south (Cyprus-Kevan), an overthrust to the north (Antalya), or a combination of both.

2) Hypothesis C. In this case, a marginal basin developed south of the Apulia-Anatolia microplate during the Barremian to Campanian with the creation of oceanic crust behind an arc made of the tectonic stacking of Triassic-Jurassic Mamonia sediments. This oceanic crust could be the origin of all the ophiolitic massifs in the arc, which were tectonically emplaced during the Maestrichtian.

In each hypothesis (A, B, C, D) a subduction zone has been active in the northern part of the Tethys north of Apulia-Anatolia in its northern side since the Triassic, with a probable former marginal basin which could have been the initiation of the Black Sea (Figure 2 ). In the Late Cretaceous, the continental collision between Eurasia and Anatolia-Apulia and directly between Eurasia-Africa-Arabia to the east provoked the final consumption of the Tethys with the southward obduction of ophiolites and melange on Apulia-Anatolia and on Arabia. In hypothesis D, all the eastern Mediterranean ophiolites came from this most northern suture (a variant of the Ricou hypothesis).

\section{Geological and Geophysical Evidence of the Maestrichtian Event}

To the east in southern Turkey-northern Syria it is well established that neritic platform deposits of Late Cretaceous age passed into pelagic deposits in which, since Campanian time, olistostromes were emplaced from the north. During the Maestrichtian the nappes, including melanges and large ophiolitic massifs (Baasit, Kevan, Kizil Dagh) were emplaced all the way to the Arabian platform (cf. Figure 10) along with, superficial gravity slides. These nappes are overlain by transgressive Maestrichtian to Eocene shallow-water deposits (Rigo de Righi et al., 1964; Sungurlu, 1974). On the other side of the arcuate system in the Antalya area (Turkey), it is currently accepted that synchronous overthrusting occurred, but also that later tectonic events obscured the first event. In the middle of the arc, in the eastern Mediterranean area, evidence from Cyprus shows that Troodos ophiolites and Mamonia nappes are associated with melanges of Maestrichtian age. The substratum of these nappes is unknown, but we suggest that it could be a pelagic facies of the proto-eastern Mediterranean. Later deposits, Maestrichtian to Eocene, are considered pelagic sediments which onlap the Troodos high.

Magnetic anomaly data link these observations to land data and demonstrate the continuity of allochthonous massifs with pillow lavas and ophiolites between Syria and Cyprus, and then from Cyprus to Antalya. Towards the south, the absence of important magnetic anomalies (with exception of the southeastern part of Eratosthenes Seamount) suggests that the extent of these massifs is limited.

\section{Cenozoic Development}

Upper Eocene-Oligocene (Figures 11, 12)

Compressional events were again prevalent during late Eocene-Oligocene time. This was the time of emplacement of new nappes and folding throughout all of Turkey (Hadim, Beysehir), of olistoli deposition in North Cyprus (Kyrenia range), and even folding and reverse faulting in South Cyprus, while in the southern part of Cyprus pelagic carbonate sediments were deposited. On the back arc side and in the thrust zone, flysch sediments were being deposited in different subsident basins.

\section{Miocene}

Throughout the entire Miocene this area was subjected to continuous compression as a result of the proximity of Africa and Apulia-Anatolia. Because of the continental collision in the eastern part, accentuated by the strike-slip movement on the Levantine fault system (opening of the Red Sea and initiation of the Arabian plate), all the Anatolian area was fragmented and subjected to complex movement towards the eastern Mediterranean.

During the early Miocene neritic carbonate facies which overlap older deposits are well known in places on the borders, for example, Troodos which was an island (Pantazis, this volume), onshore Antalya, Mut and Adana areas with reefoid development (Ozer et al., 1974). In the subsided zones these facies give way to thick pelagic marls into which clastic sediments extend. Deposition of these pelagic sequences occurred throughout the Miocene and the continuing deformation is marked by olistostromes in the Misis area, internal unconformities in various places, and reverse faults in the Antalya area (in the deep basin as well as in onshore Antalya nappes).

Superimposed on this geodynamic history and controlled by active tectonics, the Messinian evaporites were deposited in more or less separate basins (Montadert et al., this volume, fig. 1). In the deepest and most rapidly subsiding zones, thick evaporites with salt were deposited in the basin (more than $1500 \mathrm{~m}$ in 
Antalya). Thin evaporites, and/or shallow carbonate facies were deposited on the high areas (around Troodos, South Turkey).

Compression was particularly active during and after the Messinian in a very broad area (see Figure $10)$. Thrusting is clearly marked along the MisisKyrenia-Antalya Basin-Gebiz Mountain axis, but also south of Cyprus and along the Florence Rise (see map, Figure 1).

Results from Sites 375-376 indicate that during the Langhian to Tortonian turbidites were deposited in the area of the Florence Rise. These turbidites are comparable to Miocene deposits in north Mesaoria in Cyprus, but different from the pelagic and neritic carbonates known around Troodos. This indicates a lower position of the Florence Rise area at that time relative to Troodos (Baroz et al., this volume). This can be explained by the presence of the large Erathosthes high just south of the Cyprus Arc, which provoked the uplift of the Cyprus thrusting zone. During and after the Messinian, as the result of overthrusting such as in the Misis or Kyrenia ranges, the Florence Rise was a high with a thin cover of evaporites $(50 \mathrm{~m})$ as compared with the very thick evaporite section deposited in the adjacent basins (see Figure 10).

Deposition of the Pliocene was controlled mainly by the distance to the sources of clastics. North of the Cyprus Arc, near the margins, important deltaic prograding deposits exist. They are especially thick (3000 $\mathrm{m}$ ) in relation to Seyhan and Ceyhan deltas in the Adana-Iskenderun Basin. Far from the margin, as demonstrated by Sites 375-376 during the PliocenePleistocene, only a very thin veneer of pelagic sediments $(50 \mathrm{~m})$ was deposited, while to the south thick sediments accumulated as a result of the Nile influx. Sedimentation in the basins was also greatly controlled by salt tectonics. Formation of diapirs trapped sediments, created depocenters, and induced slippage of the cover. Tectonism is still active today as demonstrated by field evidence which shows continuous Recent uplifting and subsidence, present-day sliding in Cyprus offshore overthrusting (shown by seismic profiles), and some earthquakes.

Vertical movements linked to the continuing compression are very important in north (Turkey) where block faulting occurred. Recent internal basins were created which contain continental deposits. The Taurus range was built very recently: certainly post-Miocene because the marine Burdigalian transgression which involved a large part of South Turkey is now at great elevations of more than 2000 meters (Ozer et al., 1974). In Cyprus, elevation of the Troodos and Kyrenia are also a result of recent uplifting.

\section{AEGEAN ARC AND MEDITERRANEAN RIDGE}

The Aegean Arc corresponds to a very broad folded belt extending from southwest Turkey to the Dinarides (Morelli et al., 1975; Jongsma, 1974, 1975). In the central part several units are distinguished, from north to south (Figures 1, 10, 13). They are: (1) the North
Aegean Sea with several highs and basins which are interpreted as tensional features on a continental area; (2) a present-day volcanic arc (Santorin); (3) an interdeep basin: the North Cretan Basin; (4) the Cretan high corresponding to a pile of nappes as known in Greece and western Turkey; (5) a complicated set of trenches: the "Hellenic trenches"; (6) the "Mediterranean Ridge" which constitutes the external envelope of the Aegean Arc; and (7) the Ionian and Herodotus abyssal plains in front of the African margin.

\section{Speculations on Mesozoic History (Figures 11, 13)}

Because of several different nappes which originated from the north have been stacked, little is known about the Mesozoic history of the southern part of ApuliaAnatolia in this area. Thus, the schematic history shown on Figure 13 is very speculative.

The Hellenides are conventionally interpreted as having resulted from the closing of the Tethys in the north, probably since the Late Jurassic (Dercourt, 1970; Aubouin et al., 1970). The closure is associated with nappes coming from very far north, but also from the shortening of the Apulia-Anatolia microplate as a result of overthrusting. We are not certain, however, whether or not a subduction zone existed south of Apulia-Anatolia, although we assume that it did exist from more general considerations (Figure 2).

\section{Cenozoic Development}

\section{Eocene-Oligocene}

Most workers believe that an important tectonic event occurred during the late Eocene-Oligocene at the level of Karpathos-Crete-Peloponesus. Nevertheless, this concept of a tectonic phase is difficult to define, especially in this area where tectonic activity has been continuous throughout much of its geological history, but where its effects have been very different from place to place at different times.

Schematically, we note the emplacement of nappes including ophiolites. These are especially prominent in Crete, and are more geographically extensive in Greece and Turkey. They include older Mesozoic nappes. In Crete, on land, there is no evidence of post-Oligocene overthrusting as opposed to southwest Turkey and Epirus where Miocenic compression occurred. After the Oligocene the overthrusting front was apparently situated offshore, southward from Crete. This front is known onland in southwest Turkey where these nappes (Lycian nappes) overthrust Miocene flysch (Figure 10).

\section{Miocene: Formation of the Mediterranean Ridge}

We emphasize that the Aegean area during the Cenozoic (Figure 11) was characterized by the northern nappes which came from the old Tethys and were only superimposed in the central part (Crete) on the overthrusts of the South Apulian-Anatolian active margin. On the external parts of the arc (Lycian area, Epirus zone) the front of the northern nappes still lay on the dislocated continental Apulia-Anatolia. Then, during the Miocene, compressional tectonics affected a 


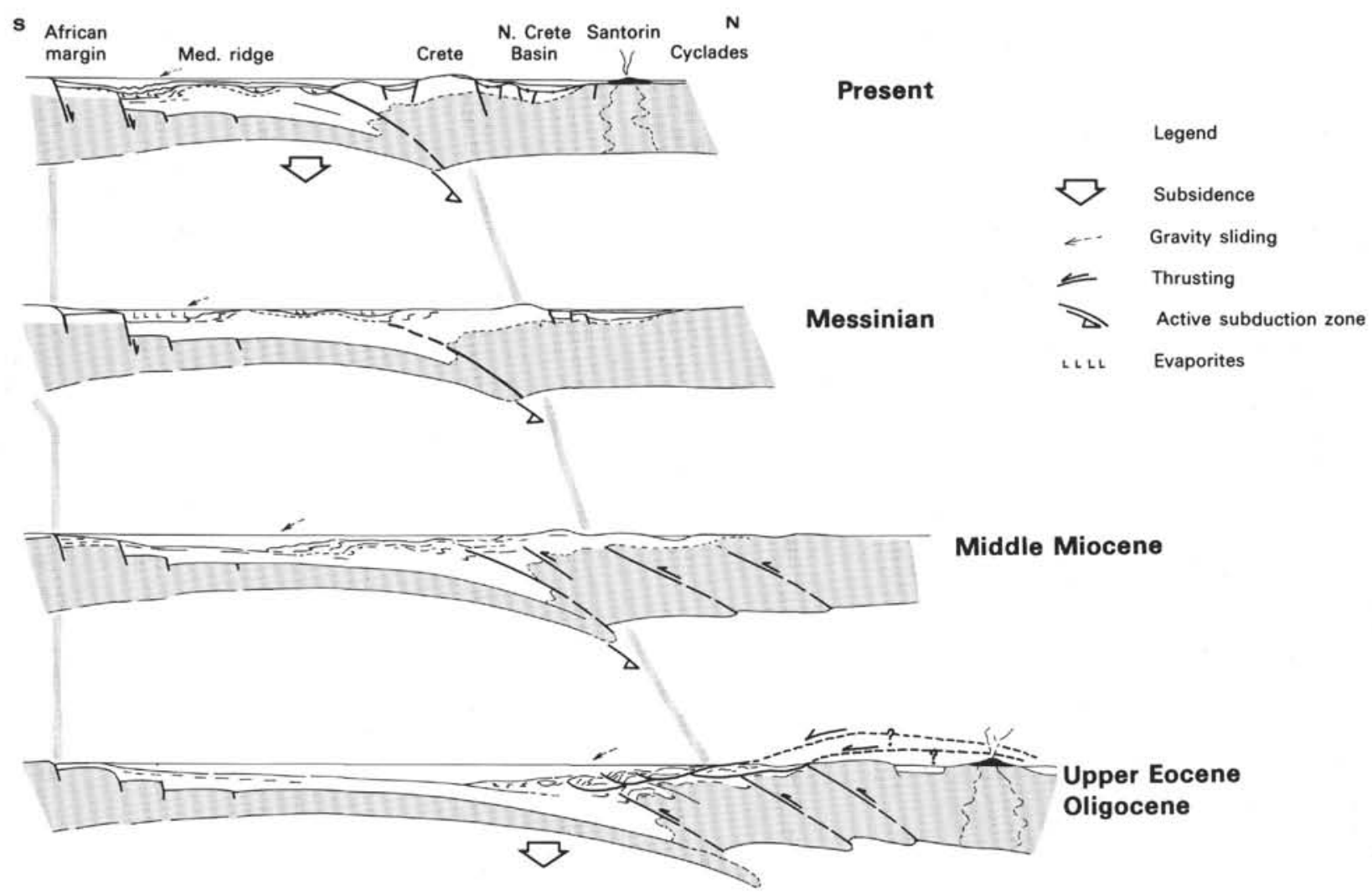

II Neogene-Recent

\section{Mesozoic-Paleogene}

Upper Eocene - Oligocene

Late Cretaceous

Upper Jurassic

Liasic

Triasic
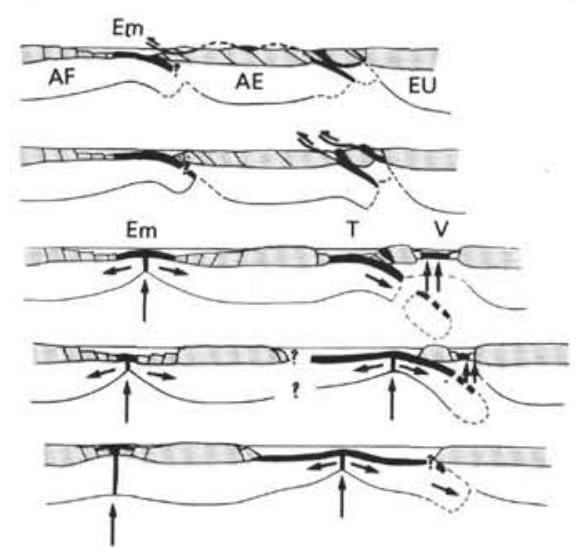

AF : Africa

$A E$ : Aegean (Apulia)

EU : Europe

$V:$ Vardar

Em : Eastern Med.

Figure 13. Tentative geological evolution of the Aegean Arc.

large area of the eastern Mediterranean basins. We think that this also explains the formation of the Mediterranean Ridge.

Previously, the ridge was defined on the basis of its bathymetry and the special morphology of the sea floor. Then drilling (Leg 13, Ryan, Hsü, et al., 1973) and seismic profiling provided some new elements for interpretation (Rabinowitz et al., 1970; Ryan, 1969). They interpreted the ridge as an imbricated tectonic pile dating back 10 million years. Sancho et al. (1973) showed that some quiet basins existed on the ridge. Mulder (1973) and Biju-Duval et al. (1974) interpreted it as a broad gravity slide, Messinian to Recent, and middle Miocene in age, respectively. Finetti et al. (1974) interpreted it as recent thrusts of MesozoicCenozoic sediments similar to the eastern Adriatic folded belt.

Taking into account the results from Hole 377 (Site 377 Report, this volume), the re-examination of data of previously drilled holes, the seismic reflection pro- 
files, comparison with seismic profiles in other active margins of the world, and the location of seismicity north of the ridge in the Hellenic trenches, we propose the following interpretation. The Mediterranean Ridge forms a crescent only in front of the Aegean Arc where nappes coming from the north and southern active margins are superimposed (Fiqure 11). During Miocene time, the Aegean area probably was already a new small subplate (McKenzie, 1972). Continuous compression south of this plate may have caused the formation of a sedimentary wedge by accretion of the very thick piles of sediments in the southern subsiding eastern Mediterranean Basin.

This feature is similar to structures in different parts of the world (e.g., Barbados Ridge) where sediments have been primarily disturbed (reverse faults, collapse, slumps, melanges) in the frontal part of the accretion zone, but remain undisturbed behind where quiet sedimentation occurs. This phenomenon migrates with time, and we suggest that it occurred during the Miocene south of Crete.

Deep Sea drilling results show that during the early and middle Miocene continuous pelagic and/or flyschtype sedimentation occurred in the northern part of the ridge. The southern part may have been disturbed, partly with gravity slides, at the same time which could, in part, explain the absence of coherent reflectors on the seismic profiles.

In the late Miocene (Figure 13) during the deposition of evaporites, the mechanism was still active. Some not-very-disturbed salt basins are present in the northern part of the ridge, whereas in the south very thick salt basins pinch out northward, demonstrating that the ridge was a high. In this southern part, in contrast to the north, the bottom of the salt is not well defined. This suggests that part of the salt was imbricated in the frontal sliding far from the subduction zone (Figure 10).

The present topography was initiated in the late Miocene, as it is clearly defined by the evaporite distribution (see fig. 1, Montadert, this volume). The region is particularly high from southwestern Crete to southwestern Peloponesus, and its elevation might be a result of the formation of a swell south of the trenches. This phenomenon is still active today and could provoke sliding of the southern part of the ridge because of the existence of a thick salt layer. North of the ridge the deep trenches are related to the subduction zone marked by intense earthquake activity.

In conclusion, in spite of evident differences of setting and of unconclusive seismic data, we interpret the Mediterranean Ridge as a tectonic feature somewhat similar to the Barbados Ridge (Mascle et al., in press).

\section{Calabrian Arc}

The Calabrian Arc, like the Aegean Arc, has been compared with the circum-Pacific subduction zone because of its general arcuate arrangement, seismicity, and volcanism. Nevertheless, the setting of the Calabrian Arc is not so simple. This structure runs from the
Molise Basin where Apennines overthrusts lie on the continental Apulia block (Figures 8, 11) to Sicily where a similar situation exists between northern nappes and the African continent (Siculo-Tunisian platform) through the Calabria and Messina cone in front of the Ionian Abyssal Plain. If we consider the Mesozoic history, we note the particular location of this area between the Iberian, Apulian, and African plates (Figures 11, 14). Geological data are limited because of the small size of the emerged area (North SicilyCalabria) and because recent tectonic activity has obscured the older events. Speculative interpretations lead us to conclude that in late Eocene times a Calabrian active margin developed on the eastern border of the Iberian plate (Figure 8) which consumed the western Tethys, and caused the formation of an intrasutural basin behind (proto-Tyrrhenian). Since that time the development of the Calabrian Arc has been linked to the history of the North-Algerian margin. But since the Oligocene it has differed from the Maghrebian area as explained later.

\section{Neogene-Recent Evolution}

During the entire Miocene the Calabrian Arc was very active. Land data demonstrate that several nappes, with numerous olistolites and olistostromes, were emplaced between Burdigalian and Tortonian times in subsided basins which were progressively deformed towards the external zone. Both in Sicily and along the Apennines, deformations and external gravity sliding continued during the late Miocene, Pliocene, and even into Quaternary time.

The seismic offshore data are compatible with this geological interpretation of onshore evolution, but differs in that it shows that the active zone in this central part (Ionian Sea) is in front of a deep marine area. In the Apennines and North Africa-Sicily the subduction zone is closed by continental areas and the existence of the deep Ionian Sea with an oceanic or intermediate crust may explain the great extent of the thrusts, folds, and gravity slidings in the Calabrian margin.

Behind the external zone (Calabria) the opening of the Tyrrhenian Sea continued, probably as a marginal type basin with extended volcanism. This volcanic activity was still active in Messinian and even in Pliocene times as evidenced by drilling at Hole 373 (see Site 373 Report, this volume). The Calabrian Basin perhaps represents an interdeep basin whose age of formation is unknown.

During Messinian time a thick salt layer was deposited in the Ionian Sea on a very thick sedimentary cover. The salt was deposited above and in front of the thrust zone (Figures 10,14) and became overlain by shallow water evaporites (see Site 374 Report, this volume).

A broad part of the Messina Cone is thus interpreted as a result of the salt flowing in front of a highly tectonized area linked to subduction (Figures 1, 10). It is difficult to distinguish the Messina Cone from the Mediterranean Ridge north of the Ionian Abyssal 

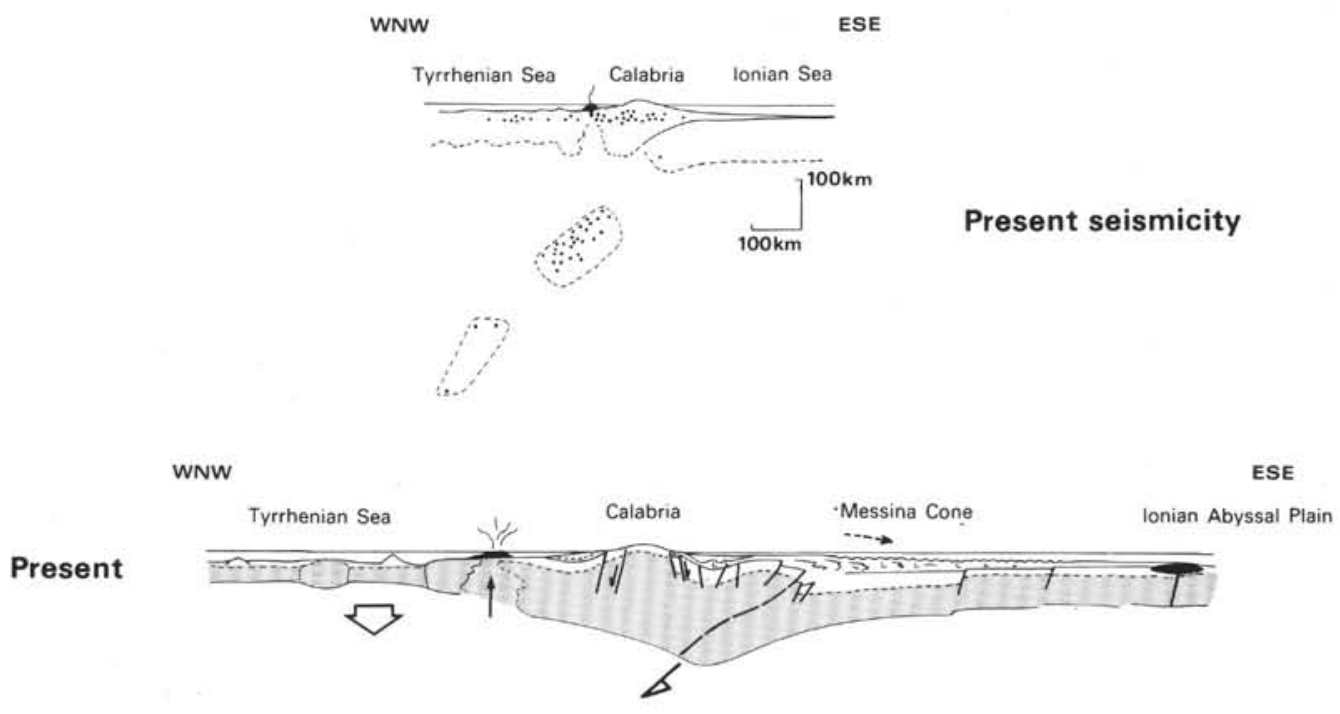

Messinian

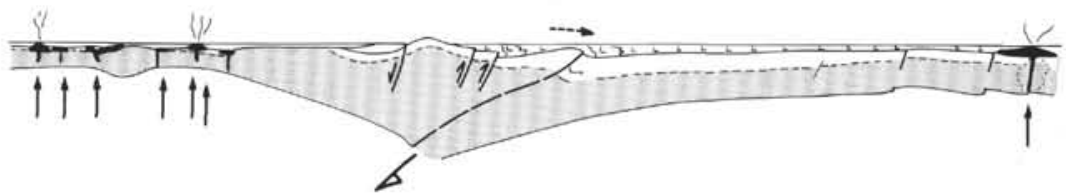

Middle Upper Miocene
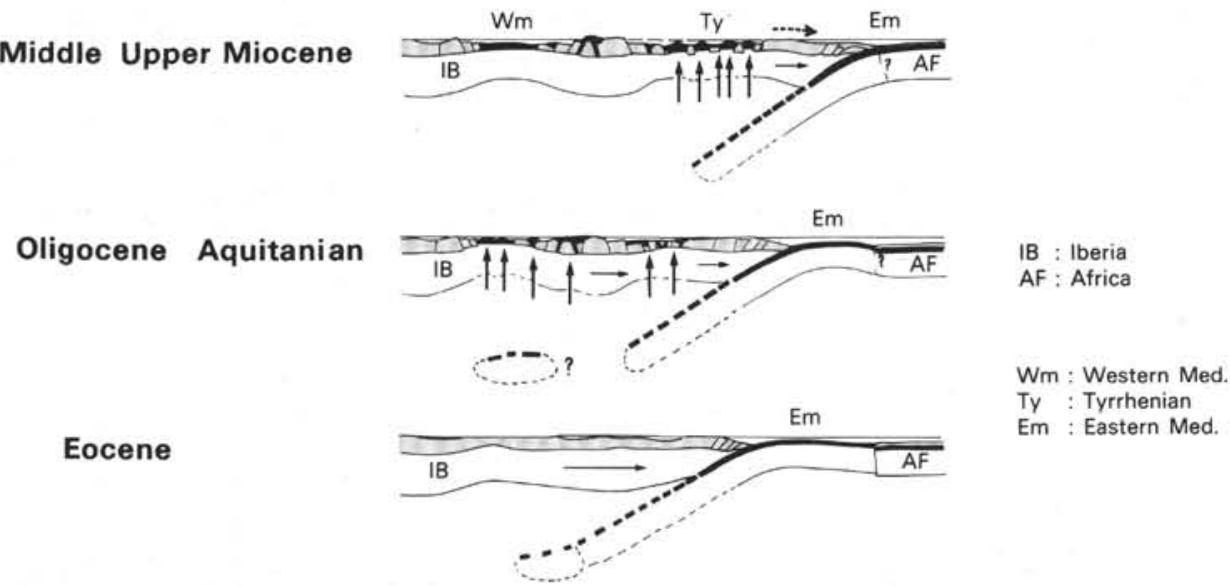

Figure 14. Tentative geological evolution of the Calabrian Arc.

Plain. Indeed the two structures are connected in a zone where the seismic profiles show very similar features. We think this is because the two fronts met in an area where there is a thick salt basin and thus the disturbances affecting Pliocene-Quaternary sediments are very similar although the two original structures were discrete features.
IFP site surveys for Hole 374 showed that the thick sedimentary sequence of the Messina Abyssal Plains below the salt is affected by faulting and folding and volcanism (Figure 15). The origin and significance of the tectonism is not well established. The zone might be interpreted as a large fracture zone running southwest-northeast from the Medina mountains to West 
Kephalonia (Ionian Islands) and possibly through Hellenides (?).

The analysis of these three arcuate systems north of the eastern basin and their interpretations show that the evolution of the eastern Mediterranean cannot be looked upon as a single series of events. The ancient history is difficult to retrace, and it is probable that the paleogeography was not so simple as previously described. We can interpret the evolution of the area since Maestrichtian time, but we are obliged to recognize the existence of several basins. The tectonic development was related to continental collision and the diversity of the northern active margins was caused by the fragmentation of the initial Apulian-Anatolian plate now broken into the Apulian, Aegean, and Anatolian subplates. This explains why several areas have been subjected to different intensities of deformation, evolution of magmatism.

\section{CONCLUSIONS}

The data and interpretations presented here are derived from six years of investigations in the offshore and onshore Mediterranean area. In spite of a short (selected) bibliography, the interpretations are also made on the basis of a very broad survey of numerous previous data. The Mediterranean is the subject of thousands of theses and numerous surveys, and offshore research is becoming more and more developed. This paper also incorporates our own knowledge of other investigated areas, such as offshore active margins (Caribbean, southwest Pacific), stable margins, or even onland areas surveyed earlier. Also DSDP data and the contributions dealing with plate tectonics were considered. With the development of geophysics and the DSDP program, a big step forward has been taken.

Clearly, the very important results from the DSDP holes (Legs 13 and $42 \mathrm{~A}$ ) are of greatest value if they are considered in a structural context. This is the purpose of this paper. Onshore and offshore relationships are shown by geological cross-sections. The recent evolution of deep basins and thin margins are presented by cross-sections, and general speculations about their older history are noted and will be presented in detail later (in collaboration with Dercourt and Le Pichon). Because of this synthetic presentation, readers will have to distinguish the speculative from the well-established data. We believe, however, that is important to make this updated review and to introduce some general interpretations at this time.

\section{Differing types of basins in the Mediterranean}

In spite of an apparent uniformity because of recent filling (a late Miocene with widespread evaporites and a Pliocene-Quarternary with prograded clastics), the Mediterranean basins are basically different. None of them (North Balearic, South Balearic, Tyrrhenian, Adriatic, Ionian, Aegean, Levantine) have the same history. Nevertheless, two broad types of tectonic settings are recognized: (1) basins within orogenic regions or those related to them (marginal basins); (2) basins between stable margins and orogenic regions (East Mediterranean).

\section{Two major types of tectonic acitivity: Tethyan and Mediterranean}

The ancient history is related to a large ocean, and the recent history is related to continental collision. In the former, the Tethyan history of subduction and obduction prevailed. We can compare its history with a normal large ocean and its adjacent basins. In the latter, the Mediterranean history of compression and distension are compared with the type of tectonism presently occurring in the Mediterranean, as described by McKenzie (1972).

\section{Answers to the ancient history are on land}

In its initial state, the Tethys was similar to oceanic areas such as the Pacific or Atlantic. To understand these areas, however, we must be very prudent because structure and paleogeography along stable and active margins are not simple. The answers to our (and other) speculations may be found onshore. Many scientists are now trying to find proof of the initiation of margins, the existence of ancient subduction, or evidence for related events in Alpine outcrops. On the other hand, it is clear that to ensure progress in the study of the Alpine belt we must consider oceanic data such as that from the Deep Sea Drilling Project and studies of global tectonics.

\section{Problems of ancient tectonic events (ancient subductions and obductions)}

We cannot precisely locate the areas of subduction and obduction during the Tethyan history because the exact sizes of oceanic realms are unknown. Geophysicists cannot easily define (even on present margins) the transition zone between continent and ocean. Moreover the mechanisms of subductions and obductions are still not resolved and are the subject of debate (see, for example, Dewey, 1976). Furthermore, a very great uncertainty exists as to the location of Africa and Eurasia before Late Cretaceous time (Biju-Duval et al., 1976, 1977) and because ages of the ophiolites and knowledge of the melanges are uncertain or incomplete.

\section{Importance of magmatism}

The extension of offshore volcanism is very great in the Mediterranean. The Tyrrhenian Sea and western Mediterranean are marked by the numerous Neogene or Quaternary structures and indeed contrast with the eastern Mediterranean (Ionian, Herodotus, Levantine basins) where recent volcanoes are limited. In spite of the restricted development of onshore volcanoes or volcanoclastic series in the area, several authors have used them as a basis to define recent subduction zones. Here we must bear in mind the scale of the phenomenon. For example, the few occurrences of typical andesitic series in the Neogene of the western Mediterranean is very different from (1) the broad Late Cretaceous andesitic arc of the Balkans-Pontids-Caucasus located behind the ophiolitic suture and (2) the well-developed Lias-Jurassic volcanism of the Pon- 

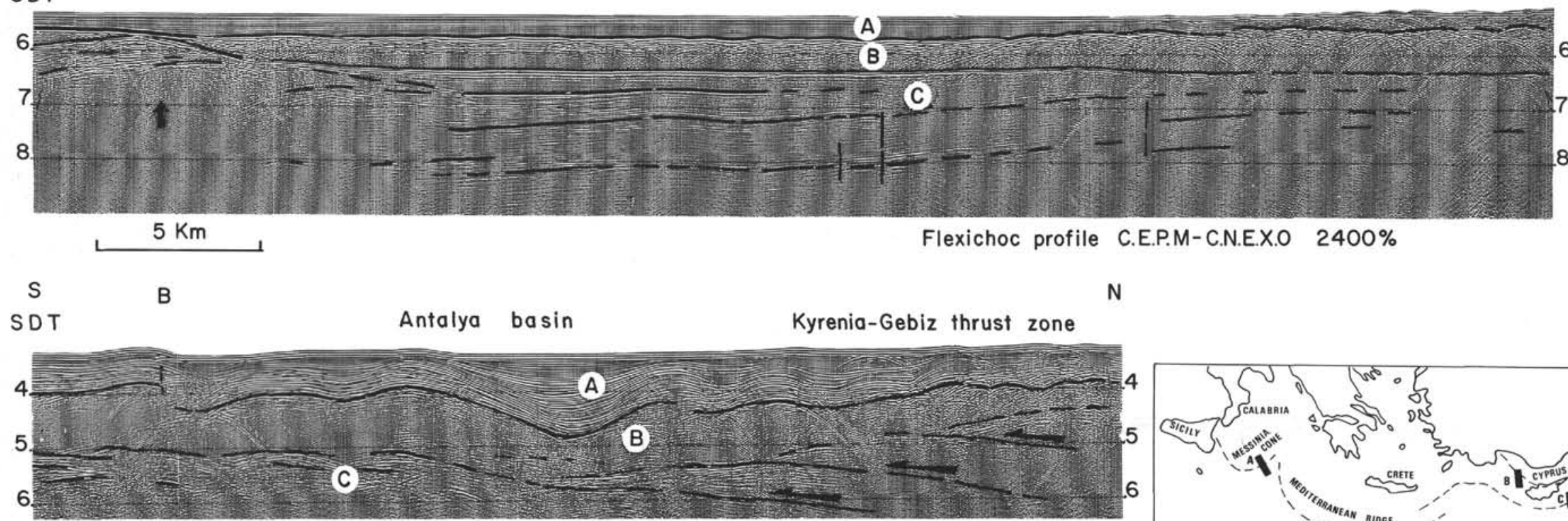

N

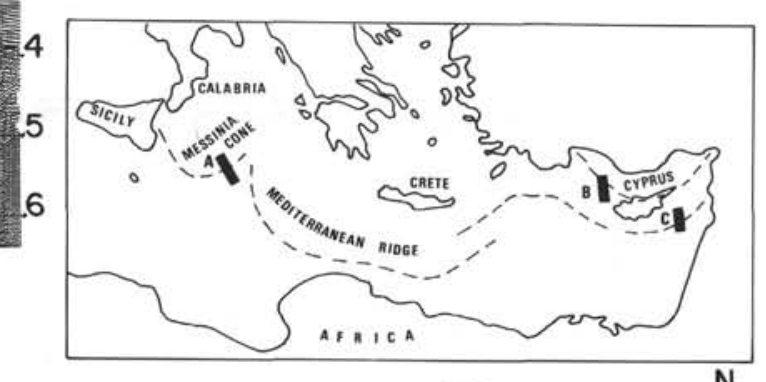

c

Flexichoc profile I.F.P.-C.N.E.X.O $2400 \%$

$5 \mathrm{Km}$

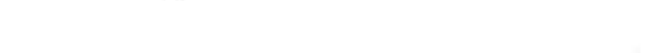

$S$ Cyprus Arc:

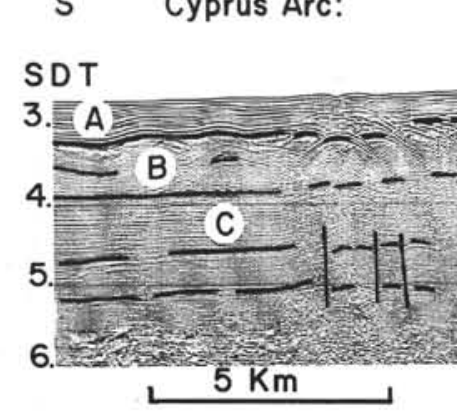

\section{A Pliocene Quaternary}

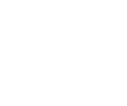

N

Figure 15. Examples of seismic reflection profiles in the Eastern Mediterranean.

\section{Flexichoc profile I.F.P-C.N.E.X.O. $2400 \%$}


tides-Caucasus. These differences are certainly related to the initial size of tbe adjacent ocean which had never been extensive in the western Mediterranean but in contrast was very large in the eastern Mediterranean (Figure 2).

The nature of the magmatism must also be kept in mind. For example, Pliocene-Quaternary basalts are very common throughout very large areas, but andesitic magmatism occurred only locally during the same time. Moreover, in one place magmatic differentiation was very great over a period of time. Because magmatism is one of the bases for determining fossil subduction zones, we must make a great effort to clarify the occurrence and effects of all these aspects in the Mediterranean.

\section{Recent tectonics characteristic of the Mediterranean}

It is very difficult to compare the present Mediterranean tectonic activity with classic examples (Himalayan type or Pacific type) because it is a special case and corresponds to an intermediate stage. Indeed, the Mediterranean is an area which could provide an example of an intermediate stage for comparison with other areas, yet to be described.

\section{Continuity of tectonic events}

Geologists, especially those that study the Mediterranean Sea, insist on referring to paleotectonics, tectonics, tarditectonics, and neotectonics. Taking into account the relationship between deformation and plate movements the distinction of separate phases is not this clear. Tectonic phenomena are instead continuous. Moreover, the notion of post-tectonic deposits is not at all evident. In many places "post-tectonic" basins are later displaced with their tectonized basement (Apennines, Lycian nappes) without great deformation although the horizontal displacement may be important. Often many young deposits, directly on a subduction zone (Aegean area, North Algerian margin), are affected by Recent up thrusting, reverse faulting, etc. At the same time compressional and distensional tectonics occurred in different places.

\section{Importance of gravity slides are related to the compressional effects of subduction}

In different areas and in different ages, olistoliths, exotic masses, olistostromes, and gravity nappes take on great importance in the Mediterranean area. Such phenomena are not inconsistent with the concept of accretions in a subduction zone. On the contrary, they are related. This epiphenomenon may be highly developed, especially where the slope and the quantity of material are great. Their occurrence is of great significance because their first appearance is often evidence of an active margin.

\section{ACKNOWLEDGMENTS}

We are indebted to V. Apostolescu, P. Courrier, and R. Gonnard of I.F.P. with whom our data was collected; to J. Dercourt (Lille University) and X. Le Pichon (CNEXO) for helpful discussions, hard work on Mesozoic problems and their critical reviewing of the manuscript; to A. Mauffret (Paris VI, University) for numerous discussions and to J. Debyser (CNEXO) and C. Salle (I.F.P.) who reviewed this paper. We thank also our colleagues in the petroleum industry for numerous and interesting discussions on Mediterranean problems.

\section{REFERENCES}

Alvarez, W., 1972, Rotation of the Corsica Sardinia microplate: Nature, Phys. Sci., v. 235, p. 103-105.

Alvarez, W., Cocozza, T., and Wezel, F. C., 1974. Fragmentation of the Alpine orogenic belt by microplate dispersal Nature, Phys. Sci, v. 248, p. 309-314.

Arana V. and Vegas R., 1974. Plate tectonics and volcanism in the Gibraltar Arc: Tectonophysics, v. 24, p. 197-212.

Argyriadis, I., 1974. Sur 1'Orogenèse mésogéenne des temps crétacés Rev. Geog. Phys. Geol. Dyn., v. XVI, p. 23-60. , 1975. Mésogée permienne, chaine hercynienne et cassure téthysienne: Soc. Geol. France Bull., v. 17, p. 5670.

Arthaud F. and Matte, P., 1975. Les décrochements tardihercyniens du SW de I'Europe. Géomètrie et essai de reconstitution des conditions de la déformation: Tectonophysics, v. 25, p. 139-171.

Aubouin, J., Blanchet, R., Cadet, J. P., Celet, P., Charvet, J., Chorowicz, J., Cousin, M., and Rampnoux J. P., 1970. Essai sur la géologie des Dinarides: Soc. Géol. France, Bull., v. 12, p. 1060-1095.

Aubouin, J., 1973. Paléotectonique, tectonique, tarditectonique et néotectonique en Méditerranée moyenne: Geol. Soc. Greece, Bull., v. 10, p. 3-10.

Auzende, J. M., Bonnin, J., and Olivet, J. L., 1973. The origin of the Western Mediterranean Basin: J. Geol. Soc. London, v. 129 , p. 607-620.

Auzende, J. M., Olivet, J. L., and Bonnin, J., 1972. Une structure compressive au Nord de l'Algérie: Deep-Sea Res., v. 19, p. 149-155.

Bally, A. W., 1975. A geodynamic scenario for hydrocarbon occurrences: World Petrol. Congs. Tokyo, p. 33-44.

Bayer, R., Le Mouel, J. L., and Le Pichon, X., 1973. Magnetic anomaly pattern in the western Mediterranean: Earth Planet. Sci. Lett., v. 19, p. 168-176.

Bellaiche, G., Mauffret A., and Rehault, J. P., 1974. Nature, âge et origine des affleurements rocheux prélevés par 2400 mètres de fond sur le sommet d'un dôme au large de la Provence: C. R. Acad. Sci. Paris, v. 278, p. 41-43.

Bellon, H., 1976. Séries magmatiques néogènes et quaternaires du pourtour de la Mediterranée occidentale, comparées dans leur cadre géochronométrique-implications géodynamiques: Thèse, Paris-Sud., p. 1-367.

Bernoulli, D., 1972. North Atlantic and Mediterranean Mesozoic facies: a comparison: In Hollister, C. D., Ewing, J. I., et al., Initial Reports of the Deep Sea Drilling Project., Volume 11: Washington (U.S. government Printing Office), p. 801-871.

Bernoulli, D., and Jenkyns, H. C., 1974. Alpine, Mediterranean and central Atlantic Mesozoic facies in relation to the early evolution of the Tethys. In Dott, R. H., and Shaver, R. H. (Eds), Modern and ancient geosynclinal sedimentation: p. 129-160.

Biju-Duval, B., 1974. Commentaires de la carte géologiéue et structurale des bassins tertiaires du domaine Méditerranéen: Rev. Inst. France Pétrol., v. 29, p. 607-639.

Biju-Duval, B., Letouzey, J., Montadert, L., Courrier, P., Mugniot, J. F., and Sancho, J., 1974. Geology of the Mediterranean Sea Basins. In Drake, C. A. and Burk, C. 
L. (Eds), The Geology of continental margins: New York (Springer-Verlag), p. 695-721.

Biju-Duval, B., Bizon, G., and Bizon J. J., 1974. Données nouvelles et problèmes concernant le Néogène méditerranéen à terre et en mer: Abstract, 24th Congr., CIESM Monaco.

Biju-Duval, B., Dercourt, J., and Le Pichon, X., 1976. La genèse de la Méditerranée: La Recherche, v. 7, p. 811822.

Biju-Duval, B., Dercourt, J., and Le Pichon, X., 1977. From the Tethys Ocean to the Mediterranean Seas: a plate tectonic model of the evolution of the western Alpine system. In Biju-Duval, B. and Montadert, L. (Eds), Symposium on the geological history of the Mediterranean basins: Paris (Technip), p. 143-164.

Biju-Duval, B., Lapierre, H., and Letouzey, J., 1976. Is the Troodos Massif (Cyprus) Allochthonous? Soc. Geol. France Bull., v. 18, p. 1347-1356.

Blanchet, J., 1974. Contribution à l'étude géologique des Dinarides. Un profil en Yougoslavie de la Dalmatie moyenne au Bassin Pannonique: Thèse, Paris.

Blumenthal, M., 1948. Un aperçu de la géologie des chaines nord-anatoliennes entre l'oua de Bolu et le Kizilirmak inférieur: Bull. MTA, sér. B, p. 135-153.

1963. Le système structural du Taurus sud-anatolien, Livre à la mémoire du Professeur P. Fallot: Mém. H. S. Soc. Géol. France, v. 2, p. 611-662.

Bobier, C., 1974. La signification de l'aimantation rémanente des laves de la série "des ignimbrites inférieures." Conséquence pour l'étude de la rotation du Bloc Corso-Sarde durant le tertiaire. In Paleogeographia del Terziario sardo nell ambito del Mediterraneo occidentale: Sem. Univ. Cagliari, p. 35-56

Bobier, C. and Coulon, C., 1970. Résultats préliminaires d'une étude paléomagnétique des formations volcaniques tertiaires et quaternaires du Logudoro (Sardaigne septentrionale): C. R. Acad. Sci. Paris, v. 270, p. 1434-1437.

Boccaletti, M. and Guazzone, G., 1974. Remnant arcs and marginal basins in the Cainozoic development of the Mediterranean: Nature, v. 252, p. 18-21.

Boccaletti, M., Manetti, P., and Peccerillo, A., 1974. Hypotheses on the plate tectonic evolution of the CarpathoBalkan arcs: Earth Planet. Sci. Lett., v. 23, p. 193-198.

Bosellini, A. and Hsü, K. J., 1973. Mediterranean plate tectonics and Triassic paleogeography: Nature, v. 244, p. 144-146.

Bourbon, M., Graciansky, P. Ch. de, Lemoine, M., MegardGalli, J., and Mercier, D., 1975. Platform carbonate and pelagic condensed sequences, mesozoic of the Briançonnais zone (French Alps): Intern. Congr. Sedimentol., Exc. 5 , p. 1-155.

Bourcart, J., 1963. La Méditerranée et la révolution du Pliocène, Livre à la mémoire du Professeur P. Fallot: Mém. H. S. Soc. Géol. France, v. 1, p. 103-116.

Bourgois, J., 1975. Présence de brèches d'origine sédimentaire à éléments de Crétaceé au sein "Trias germanoandalou". Hypothèses sur la signification de cette formation (Andalousie, Espagne): Soc. Géol. France Bull., v. 17, p. 1092-1100.

Bourrouilh, R., 1973. Stratigraphie, sédimentologie et tectonique de l'ile de Minorque et du nord-est de Majorque: Thèse, Paris, p. 1-822.

Bousquet, J. C., 1972. La tectonique récente de I'Apennin Calabro-Lucanien dans son cadre géologique et géophysique: Thèse, Montpellier, p. 1-172.

Bousquet, J. C. and Montenat, C., 1974. Présence de décrochements nord-est-sud-ouest plioquaternaires dans les Cordillères bétiques orientales (Espagne) Extension et signification générale: C. R. Acad. Sci. Paris, v. 278, p. 2617-2620.

Brunn, J. H., Dumont, J. F., Graciansky, P. Ch. de., Gutnic, M., Juteau, Th., Marcoux, J., Monod, O., and Poisson, A., 1971. Outline of the geology of the western Taurids. In Campbell, A. S., (Ed.), Geology and History of Turkey; Tripoli, p. 225-255.

Burollet, P. F., 1967. General geology of Tunisia and Tertiary geology of Tunisia. In Guidebook to the geology and history of Tunisia: Amsterdam (Holland-Breumelhof), p. 51-58 and 215-225.

Burollet, P. F. and Byramjee, R., 1974a. Evolution géodynamique de la Méditerranée occidentale C.R. Acad. Sci. Paris, v. 278, p. 1321-1324.

1974b. Réflexions sur la tectonique globale, exemples africains et Méditerranéens: Notes et Mém., CFP, p. 71-120

Burollet, P. F., Said, A., and Trouve, Ph., 1977. Slim holes drilled on the Algerian shelf. In Ross, D. A., Neprochnov, Yu. P., et al., Initial Reports of the Deep Sea Drilling Project, Volume 42B: Washington (U.S. Government Printing Office).

Caire, A., 1974. Eastern Atlas. In Spencer, A. M., (Ed.), Mesozoic-Cenozoic orogenic Belts: Edinburgh (Scottish Acad. Press), p. 47-59.

Carey, S.W., 1958. A tectonic approach to continental drift. In Carey, S.W., (Ed.), Continental drift: Tasmania (Hobart), p. 177-355

Chabrier, G. and Fourcade, E., 1975. Sur le Jurassique du nord-ouest de la Sardaigne: C.R. Acad. Sci. Paris, v. 281, p. 493-496.

Chabrier, G. and Mascle, G., 1975. Comparaisons des évolutions géologiques de la Provence et de la Sardaigne: Rev. Géogr. Phys. Géol. Dyn., v. 17, p. 121-136.

Coque, R. and Jauzein, A., 1965. Essai d'une carte néotectonique de la Tunisie au: 1:1000,000; Rev. Géogr. Phys. Géol. Dyn., v. 7, p. 253-265

Coulon, C., Demant, A., and Bobier, C., 1974. Contribution du paléomagnétisme à l'étude des séries volcaniques cénozoiques et quaternaires de Sardaigne Nord-Occidentale: Tectonophysics, v. 22, p. 59-82.

Cravatte, J., Dufaure, Ph., Prim, M., and Rouaix, S., 1974. Les forages du Golfe du Lion, stratigraphie, sédimentologie Notes et Mém., CFP, p. 209-274

Delteil, J., Fenet, B., Guardia, P., and Polveche, J., 1971. Géodynamique de l'Algérie nord-occidentale: C.R. Som. Soc. Géol. France, v. 8, p. 414-417.

Dercourt, J., 1970. L'expansion océanique actuelle et fossile: ses implications géotectoniques: Soc. Géol. France, Bull., v. 12 , p. 261-317.

Dewey, J.F., 1976. Ophiolite obduction: Tectonophysics, v. 31, p. 93-120.

Dewey, J.F., Pitman, W.C., III, Ryan, W.B.F., and Bonnin, J., 1973, Plate tectonics and the evolution of the Alpine system: Geol. Soc. Am. Bull., v. 84, p. 3137-3180.

Dubois, R., 1970. Phases de serrage, nappes de socle et métamorphisme alpin à la jonction Calabre-Apennin: la suture calabro-apenninique. Rev. Géogr. Phys. Géol. Dyn., v. 12, p. $221-254$.

Dumont, J.F., Gutnic, M., Marcoux, J., Monod, O., and Poisson, A., 1972. Le Trias des Taurides occidentales (Turquie). Définition du bassin pamphyllien: un nouveau domaine à ophiolites à la marge externe de la chaine taurique: Z. Dtsch. Geol. Ges., v. 123, p. 385-409. 
Durand-Delga, M., 1960. Mise au point sur la structure du Nord-Est de la Berbèrie: Publi. Serv. Geol. Algérie (N.S.), p. 89-131.

Enay, R., 1972. Paléobiogéographie des Ammonites du Jurassique terminal (Tithonique-Volgien-Portlandien 1.s.) et mobilité continentale: C.R., Soc. Geol. France, p. 163168.

Elter, P., Giglia, G., Tongiorgi, M., and Trevisan, L., 1975. Tensional and compressional areas in the recent (Tortonian to present) evolution of the Northern Apennines: Boll. Geof., v. 17, p. 3-18.

Fahlquist, D.A. and Hersey, J.B., 1969. Seismic refraction measurements in the Western Mediterranean Sea: Bull. Inst. Océanogr. Monaco, v. 67, p. 1-52.

Finetti, I. and Morelli, C., 1973. Geophysical exploration of the Mediterranean Sea: Boll. Geofis. Teor. Appl., v. 15, p. 263-341.

1974. Geophysical study of the Eastern Mediterranean (abstract): CIESM Congress, Monaco.

Fourquin, C., 1975. L'Anatolie du Nord-Ouest, marge méridionale du continent européen, histoire paléogéographique, tectonique et magmatique durant le secondaire et le tertiaire: Soc. Geol. France Bull., v. 17, p. 1058-1070.

Freund, R., Goldberg, M., Weissbrod, T., Druckman, Y., and Derin, B., 1975. The Triassic-Jurassic structure of Israel and its relation to the origin of the eastern Mediterranean: Geol. Surv. Israel Bull., v. 65, p. 1-26.

Gennesseaux, M., Auzende, J.M., Olivet, J.L., and Bayer, R., 1974. Les orientations structurales et magnétiques sousmarines au Sud de la Corse et la dérive corso-sarde: C.R. Acad. Sci. Paris, v. 278, p. 2003-2006.

Ginzburg, A., Cohen, S.S., Hay-Roe, H., and Rosenzweig, A., 1975. Geology of Mediterranean shelf of Israël: Am. Assoc. Petrol. Geol., Bull., v. 59-11, p. 2142-2160.

Glangeaud, L., 1971. Evolution géodynamique de la mer d'Alboran et de ses bordures. La phase messino-plioquaternaire (résumé): C.R., Soc. Géol. France, p. 431433.

Gonnard, R., Letouzey, J., Biju-Duval, B., and Montadert, L., 1975. Apports de la sismique réflection aux problèmes du volcanisme en Méditerranée et à l'interprétation des données magnétiques: Abstract in third Réun. Ann. Sci. Terre Montpellier, p. 171.

Graciansky, P. Ch. de., 1972. Recherches géologiques dans le Taurus lycien: Thèse, Paris, Sud-Orsay, v. 1, p. 1-541,

Gvirtzman, G. and Buchbinder, B., in press. The late tertiary of the coastal plain and continental shelf of Israel and it's bearing on the history of the Eastern Mediterranean. In Ross, D. A., Neprochnov, Yu. P., et al., Initial Reports of the Deep Sea Drilling Project, Volume 42B: Washington (U.S. Government Printing Office).

Haccard, D., Lorenz, C., and Grandjacquet, C., 1972. Essai sur I'évolution tectogénétique de la liaison Alpes-Apennins (de la Ligurie à la Calabre): Mém. Soc. Géol. Ital., v. 2, p. $309-341$

Hinz, K., 1972. Results of seismic refraction investigations (Project Anna) in the western Mediterranean Sea, South and North of the Island of Mallorca. In Results of the Anna cruise par O. Leenhardt et al. Bull. Centre Rech. Pau, SNPA, v. 6, p. 405-426.

1974. Results of seismic refraction and seismic reflection measurements in the Ionian Sea: Geol. J., v. 2, p. 35-65.

Horstink, J., 1971. The late Cretaceous and Tertiary Geological Evolution of Eastern Turkey. In Keskin, C. and Demirmen, F. (Eds.), First Petrol. Congr. Turkey; p. 2541
Irr, F., 1975. Evolution de la bordure du Bassin Méditerranéen nord occidental au Pliocène: nouvelles données biostratigraphiques sur le littoral franco-ligure et leurs implications tectoniques: Soc. Geol. France, Bull, v. 17, p. 945-955

Jong de, K. A., Manzoni, M., Stavengat, T., Van Dijk, F., Van der Voo, R., and Zijderveld, J.D.A., 1973. Paleomagnetic Evidence for Rotation of Sardinia during the early Miocene: Nature, v. 243, p. 281-283.

Jongsma, D., 1974. Heat flow in the Aegean Sea: Geophys. J., v. 37 , p. $337-346$.

1975. A marine Geophysical Study of the Hellenic Arc: Ph.D. thesis, Cambridge, p. 1-69.

Klemme, H. D., 1958. Regional geology of circum-Mediterranean region: Am. Assoc. Petrol. Geol. Bull., v. 42, p. 477-512.

Klitzsch, E., 1970, Die Strukturgeschichte der Zentral-sahara: neue Erkenntnisse zum Dau und zur Paläogeographic eines Tafellandes: Geol. Rundschau., v. 59, p. 459-527.

Klootwijk, C. T. and Van Den Berg, J., 1975. The rotation of Italy: preliminary paleomagnetic data from the Umbrian sequence, Northern Apennines, Earth Planet, Sci. Lett., v. 25 , p. 263-273.

Laubscher, H. and Bernoulli, D., in press. Mediterranean and Tethys. In The Ocean Basins and Margins IV Mediterranean: Nairn A. E. M, Stehli, F. G. and Kanes, W. (Eds.), New York, (Plenum Publ. Corp.).

Lanteaume, M., 1958. Schéma structural des Alpes maritimes franco-italiennes: Soc. Géol. France, Bull., v. 8, p. 651674.

Le Pichon, X. and Foucher, J.P., 1972. Creation of the Western Mediterranean Basin and lithospheric plate evolution: Contrib. 86, COB, p. 1-4.

Le Pichon, X., Pautot, G., Auzende, J.M., and Olivet, J.L., 1971, La Méditerranée Occidentale depuis 1'Oliqocène. Schéma d'évolution: Earth Planet Sci. Lett., v. 13, p. 145152.

Letouzey, J., Biju-Duval, B., Dorkel, A., Gonnard, R., Kristchev, K., Montadert, L., and Sungurlu, O., 1977. The Black Sea: a marginal basin. Geophysical and geological data. In Biju-Duval, B. and Montadert, L. (Eds.), Symposium on the geological history of the Mediterranean basins: Paris (Technip), p. 363-374.

Malovitskiy, Y.P., Emelyanov, M., Kazarov, O.V., Moskalenko, V.N., Osipov, G.V., Shimkus, K.M., and Chumakov, I.S., 1975. Geological structure of the Mediterranean Sea Floor (Based on Geological-geophysical data): Marine Geol., v. 18, p. 231-261.

Mascle, A., Biju-Duval, B., Letouzey, J., Ravennes, L., and Montadert, L., 1977. Sediments and their deformations in active margins in different Geological Setting. Intern. Symp. Geodynamics in S.W. Pacific, Nouméa: Paris (Technip), p. 327-343.

McKenzie, D., 1972. Active tectonics of the Mediterranean region: Geophys. J., v. 30, p. 109-185.

Mattauer, M. and Henry, J., 1974. Pyrénées In Spencer, A. M. (Ed.), Mesozoic-Cenozoic Belts: Edinburgh (Scottish Acad. Press), p. 3-21.

Mauffret, A., 1976. Etude Géodynamique de la marge des Iles Baléares: Thèse, Paris, p. 1-137.

Mauffret, A., Fail, J. P., Montadert, L., Sancho, J., and Winnock, E., 1973. Northwestern Mediterranean sedimentary basin from seismic reflection profile: Am. Assoc. Petrol. Geol. Bull., v. 57, p. 2245-2262.

Monod, O., Marcoux, J., Poisson, A., and Dumont, J. F., 1974. Le domaine d'Antalya, témoin de la fracturation de 
la plateforme africaine au cours du Trias: Soc. Géol. France, Bull., v. 16, p. 116-127.

Montadert, L., Sancho J., Fail, J. P., Debyser, J., and Winnock, E., 1970. De l'âge tertiaire de la série salifêre responsable des structures diapiriques en Méditerranée occidentale (nord-est des Baléares): C.R. Acad. Sci. Paris, v. 271 , p. $812-815$.

Morelli, C., 1975. Geophysics of the Mediterranean: New sl. Coop. Investig. Med. Spec. Issue 7, p. 27-111.

Morelli, C., Pisani, M., and Gantar, C., 1975. Geophysical Studies in the Aegean Sea and in the Eastern Mediterranean: Boll. Geofis. Teor. Appl., v. 18, p. 127-167.

Mulder, C. J., 1973. Tectonic framework and distribution of Miocene chemical sediments with emphasis on the Eastern Mediterranean. In Drooger (Ed.), Messinian events in the Mediterranean: Amsterdam, p. 44-59.

Mulder, C. J., Lehner, P., and Allen, D. C. K., 1975. Structural evolution of the Neogene Salt Basins in the Eastern Mediterranean and the Red Sea: Geol. Mijnbow, v. 54 , p. $208-221$

Nairn, A. E. M. and Westphal, M., 1968. Possible implications of the paleomagnetic study of late Paleozoic igneous rocks of northwestern Corsica: Pal. Pal. Pal., v. 5, p. 179204.

Neev, D., Almagor, G., Arad, A., Ginzburg, A., and Hall, J. K., 1976. The Geology of the Southeastern Mediterranean: Geol. Surv. Israel, Bull., p. 1-51.

Orszag-Sperber, F., 1975. Importance régionale des deux phases regressives enrigistrées dans le Neogène de la Méditerranée occidentale: Abstract Ninth Intern. Congr. Sedim., Nice, p. 1-4.

Ozer, B., Biju-Duval, B., Courrier, P., and Letouzey, J., 1974. Geology of Neogene Basins of Antalya, Mut and Adana. In Okay and Dileköz (Eds.), Second Petrol. Congr. Turkey, p. 57-84.

Paquet, J., 1969, Etude géologique de la province de Murcie (Espagne): Mém. Soc. Géol. France, v. 43, p. 1-270.

Pomesano-Cherchi, A., 1970. Microfaune planctoniche di alcune serie mioceniche del Logudoro (Sardegna): Second Plank. Conf. Proc., Roma, p. 1003-1016.

Rabinowitz, P. D. and Ryan, W. B. F., 1970. Gravity anomalies and crustal shortening in the Eastern Mediterranean: Tectonophysics, v. 10, p. 585 .

Razvalyayev, A. V., 1971. Some distinctive aspects of the structure and geologic history of the Western Arabia rift system: Intern. Geol. Rev., v. 14, p. 738-747.

Rehault, J. P., Olivet, J. L., and Auzende, J. M., 1974. Le Bassin nord-occidental méditerranéen: structure et évolution Soc. Géol. France, Bull., v. 16, p. 281-294.

Ricou, L. E., 1971. Le croissant ophiolitique péri-arabe. Une ceinture de nappes mises en place au Crétacé supérieur: Rev. Géogr. Phys. Géol. Dyn., v. 13, p. 327-350.

Ricou, L. E., Argyriadis, I., and Lefêvre, R., 1974. Proposition d'une origine interne pour les nappes d'Antalya et le massif d'Alanya (Taurides occidentales, Turquie): Soc. Géol. France, Bull., v. 16, p. 107-11.

Ricou, L. E., Argyriadis, I., and Marcoux, J., 1975. L'axe calcaire du Taurus, un alignement des fenêtres arabo- africaines sous des nappes radiolaritiques, ophiolitiques et métamorphiques: Soc. Geol. France, Bull., v. 17, p. 10241044.

Rigo de Righi, M. and Cortesini, A., 1964. Gravity tectonics in foothills structure belt of southeast Turkey, Am. Assoc. Petrol. Geol. Bull., v. 48, p. 1911-1937.

Rouchy, J. M., 1976. Mise en évidence de nannoplancton calcaire dans certains types de gypse finement lité (balatino) du Miocène terminal de Sicile et conséquence sur la genèse des évaporites méditerranéennes de cet âge, C.R. Acad. Sci. Paris, v. 282, p. 13-16.

Ryan, W. B. F., 1969. The floor of the Mediterranean Sea, pt. 1, Structure and evolution of the sedimentary basins, pt. 2. The stratigraphy of the eastern Mediterranean: Ph. D. thesis, Columbia University, New York, p. 189-204.

Ryan, W. B. F., Hsü, K. J., et al., 1973. Initial Reports of the Deep Sea Drilling Project, Volume 13: Washington (U. S. Government Printing Office).

Said, R., 1962. The geology of Egypt: Amsterdam (Elsevier), p. $1-377$

Salem, R., 1976. Evolution of Eocene-Miocene sedimentation Patterns in parts of Northern Egypt: Am. Assoc. Petrol. Geol. Bull., v. 60 , p. 34-64.

Sancho, J., Letouzey, J., Biju-Duval, B., Courrier, P., Montadert, L., and Winnock, E., 1973. New data on the structure of the eastern Mediterranean Basin from seismic reflection: Earth Planet. Sci. Lett., v. 18, p. 1-421.

Stanley, D. J., Got, H., Kenyon, N. H., Monaco, J., and Weiler, Y., in preparation. Catalonian, Eastern Betic and Balearic Margins: definition of structural types and relation to geologically recent foundering of the western Mediterranean Basin.

Sungurlu, O., 1974. Geology of the Northern Part of Petroleum District VI, In Okay, H. and Dileköz, E. (Eds.), Second Petrol. Congr., Turkey: p. 85-107.

Syagayev, N. A. and Sallum, G. M., 1971. Tectonics of the North-Eastern Africa (within the A.P.E. limits): USSR Acad. Sci. Proc., Geol. Ser. no. 12.

Thomas, G., 1974. La phase de compression pleistocène en Algérie nord-occidentale: âge des premiers éléments cinématiques, relations avec les mouvements en distension: C.R. Acad. Sci. Paris, v. 279, p. 311-314.

Trumpy, R., 1975. Penninic-Austroalpine boundary in the Swiss Alps. A presumed former continental margin and its problems: Am. J. Sci., v. 275A, p. 209-238.

Westphal, M., Bardou, C., Bossert, A., Hamzeh, R., 1973. A computer fit of Corsica and Sardinia against Southern France: Earth Planet. Sci. Lett., v. 18, p. 137-140.

Wezel, F. C., and Guerrera, F., 1973. Nuovi dati sulla eta e posizione strutturale del Flysch di Tusa in Sicilia: Soc. Geol. Ital. Boll., v. 92, p. 193-211.

Woodside, J. M., 1975. Evolution of the Eastern Mediterranean: Ph.D. thesis, Cambridge, p. 1-185.

Zijderveld, I. D. A. and Van der Voo, R., 1973. Paleomagnetism in the Mediterranean area. In Tarling, D. H. and Runcorn, S. K. (Eds.), Implications of continental drift to the earth sciences: New York, (Academic Press), p. 133. 161. 